\title{
Anaerobic membrane bioreactors for wastewater treatment: mechanisms, fouling control, novel configurations, and future perspectives
}

\author{
Jiajia $\mathrm{Li}^{1,2}$, Jinyuan Jiang ${ }^{2 \dagger}$, Junchao $\mathrm{Li}^{2}$, Changjun $\mathrm{He}^{2,3}$, Yong Luo ${ }^{2,4}$, Lihong Wei ${ }^{1 \dagger}$ \\ ${ }^{1}$ College of energy and environment, Shenyang Aerospace University, Shenyang 110136, Liaoning, China \\ ${ }^{2}$ Research Center of Environmental Pollution Control Technology, Chinese Research Academy of Environment Sciences, \\ Beijing 100012, China \\ ${ }^{3}$ School of Chemical and Environmental Engineering, China University of Mining \& Technology (Beijing), Beijing 100083, \\ China \\ ${ }^{4}$ College of River \& Ocean Engineering, Chongqing Jiao tong University, Chongqing 400074, China
}

Received November 18, $2021 \quad$ Revised January 16, $2022 \quad$ Accepted February 01, 2022

\begin{abstract}
As the world focuses on reducing greenhouse gas emissions and recovering energy from sewage, technologies that can recover energy and reuse wastewater are becoming increasingly important. Anaerobic membrane bioreactor (AnMBR) technology has recently attracted attention, as it can achieve energy recovery and yields high-quality effluent. However, the large-scale commercial application of AnMBRs requires that certain barriers be overcome, including membrane pollution and dissolved methane recovery. In this review article, we summarize the basic principles of anaerobic wastewater digestion and discuss the excellent performance of AnMBRs for wastewater treatment. Various factors, membrane types, and pollution are discussed, and control strategies for dealing with membrane pollution are put forward. In addition, a variety of new AnMBRs are described that may better control membrane pollution. Finally, future research directions for AnMBRs are presented to promote the large-scale integrated application of AnMBRs for industrial wastewater treatment.
\end{abstract}

Keywords: Anaerobic digestion, Anaerobic membrane bioreactor, Membrane fouling, Wastewater treatment

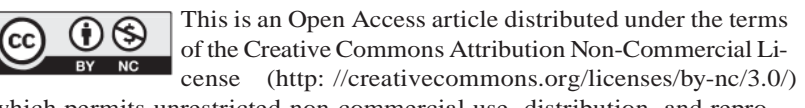
which permits unrestricted non-commercial use, distribution, and reproduction in any medium, provided the original work is properly cited.

\author{
Corresponding Author \\ E-mail: weilihong@sau.edu.cn(L.W); tiger@163.com(J.J) \\ Tel: +18040038312 \\ Tel: +13671109299 \\ ORCID: 0000-0003-3388-1978(L.W); 0000-0001-9517-4190(J.J)
}




\section{1}

2 Wastewater treatment has attracted attention in recent years due to a growing lack of

3 water resources and concurrent increase in environmental pollution caused by

4 wastewater discharge [1].Wastewater contains an abundance of materials, including

5 carbohydrates, proteins, lipids, and other reducing organic substances [2], all of which

6 are an untapped resource once the wastewater has been treated. Wastewater utilization

7 mainly depends on efficient, economical, and environmentally friendly treatment

8 technologies [3]. Conventional anaerobic digestion technologies cannot overcome

9 long sludge retention times (SRT) and hydraulic retention times (HRT), and have unstable digestion processes, resulting in poor results. Anaerobic membrane

11 bioreactor (AnMBR) technology, which is a promising wastewater treatment and 12 resource recovery technology, can capture almost all microorganisms and solids by 13 introducing membrane systems [4]. Thus, AnMBRs can overcome the limitations of traditional anaerobic digestion methods. They can effectively separate SRT and HRT, significantly reduce HRT, and increase the organic loading rate [5][7], while also improving treatment efficiency and energy recovery using wastewater. This is due to the efficient retention of the membrane modules, which makes the AnMBR a relatively closed system for microorganisms. The microorganisms in the reactor can be completely retained, achieving a complete separation of HRT and SRT, thus enabling the bioreactor to maintain a high sludge concentration, a short HRT and a long SRT, improving shock resistance and pollutant removal efficiency [8]. Moreover, 
AnMBRs improve the competitiveness and applicability of anaerobic systems for mainstream wastewater treatment processes [9][11].

As of 2020, AnMBRs have achieved remarkable success in treating wastewater. Compared to conventional aerobic technologies, AnMBRs can reduce energy consumption and sludge production. However, AnMBRs have many disadvantages, including susceptibility to severe membrane contamination, difficulty in recovering dissolved methane, insufficient alkalinity, and low $\mathrm{COD} / \mathrm{SO}^{2-}$ recovery [12], [13].

The aim of this paper is to provide a comprehensive review of the membrane contamination mechanism of AnMBR and membrane contamination control strategies by reviewing the AnMBR literature published in recent years, in order to provide a reference for AnMBR in future large-scale applications. The objectives of this manuscript are : (1) to provide an overview of AnMBR technology and mechanism; (2) to summarise the current performance of AnMBR, such as the removal of COD and methane yield; (3) to review and discuss the membrane contamination mechanism, membrane contamination influencing factors, membrane contamination control strategies and novel process configurations; (4) to highlight the need to address in order to facilitate large-scale commercial operation of AnMBR key issues to be addressed in order to promote large-scale commercial operation of AnMBR.

\section{AnMBR Overview}

\subsection{Technology Overview}


By definition, an AnMBR is a device that performs biological treatment in an anaerobic environment, utilizing various types of membranes for solid-liquid separation, including membrane separation and anaerobic digestion systems. The characteristics of conventional aerobic and conventional anaerobic treatments, as well as aerobic and anaerobic membrane bioreactors are summarized in Table S1. As shown in Table S1, AnMBRs have certain advantages in terms of anaerobic biological treatment technology and membrane separation, and they also are superior in terms of their high effluent quality, low energy consumption, and energy recovery. The anaerobic membrane bioreactor has its own shortcomings: (i) it has limited ability to remove inorganic nutrients such as nitrogen and phosphorus from the wastewater, and when the discharged water is sensitive to nitrogen and phosphorus, it cannot be discharged directly and needs to be treated in depth before it can meet the discharge standards. (ii)The start-up time of the reactor is longer than that of the aerobic reactor, and it usually takes at least 2 to 3 months before it can be started up properly. (iii) The treatment of $\mathrm{SO}_{4}{ }^{2-}$ containing wastewater produces hydrogen sulphide gas with an odour.

Depending on the relative position of the membrane modules and bioreactors, AnMBRs can be divided into two categories (Fig. 1): sidestream-AnMBRs and submerged-AnMBRs [13][20]. The membrane module in sidestream-AnMBRs is located outside the anaerobic reactor, which facilitates membrane cleaning and replacement [21]. However, the microbial flow-measured activity of sidestreamAnMBRs is low due to the shearing effect of the hydraulic cycle, resulting in broken 
sludge flocs [15]. Furthermore, the membrane module in submerged-AnMBRs is located inside the anaerobic reactor. Submerged-AnMBRs do, however, have various advantages, including their compact size, small footprint, and low energy consumption. However, membrane contamination is more problematic in submergedAnMBRs than in sidestream-AnMBRs. This is because in sidestream-AnMBRs the membrane module is located outside the bioreactor and the sludge mixture in the reactor is transferred to the external membrane module by circulation. The circulation of the mix creates strong staggered shear, which can mitigate membrane contamination of the membrane surface to some extent. In contrast, the submerged AnMBR membrane module is in direct contact with the sludge mixture and the membrane module filters the water directly from the mixture, so membrane contamination in submerged-AnMBRs is a more serious problem than in sidestreamAnMBRs.

\subsection{Methane Production from Anaerobic Digestion}

In anaerobic digestion, organic matter is broken down into $\mathrm{H}_{2} \mathrm{O}$ and $\mathrm{CO}_{2}$ through the combined action of multiple (anaerobic or parthenogenic) microorganisms in anaerobic conditions. Compared to aerobic treatments, the hydrogen receptor used in anaerobic conditions consists of chemosynthetic oxygen, carbon, sulfur, or hydrogen. Many scholars believe that methane production from anaerobic digestion can be divided into three stages: the hydrolytic fermentation stage, the hydrogen and acetic acid production stage, and the methane production stage [22]. 
hydrolytic fermentation stage, under the action of hydrolytic acidifying bacteria, complex organic matter is decomposed into soluble organic matter and then converted into fatty acids (propionic, butyric, and lactic acids), as well as alcohols (ethanol and other small molecules) [23]. The hydrolysis rate and the degree of hydrolysis are determined by the hydrolysis temperature, $\mathrm{pH}$, organic matter composition (such as lignin, or the mass fraction of protein, fat, and carbohydrates), residence time, and the concentration of hydrolysis products. During the hydrogen and acetic acid production stage, the oxidative decomposition of organic acids and alcohols occurs, specifically using molecules with three or more carbon atoms, which are produced from the hydrolytic fermentation stage, and are then converted into acetic acid, $\mathrm{H}_{2}$, and $\mathrm{CO}_{2}$. In addition, the $\mathrm{H}_{2}$ and $\mathrm{CO}_{2}$ are converted into acetic acid through the metabolism of homotypic acetic acid-producing bacteria. During the methane production phase, methane can be produced in two ways. In the first pathway, acetic acid trophic methanogenic bacteria produce methane using acetic acid as a substrate. In anaerobic reactors, about $70 \%$ of the methane is produced from the oxidative decomposition of acetic acid [24] [25]. In the second pathway, hydrogenotrophic methanogenic bacteria convert $\mathrm{CO}_{2}$ and $\mathrm{H}_{2}$ into methane, producing approximately $30 \%$ methane [26].

\subsection{Membrane Materials and Modules}

To mitigate membrane contamination and extend membrane life, a variety of membrane materials have been developed for AnMBRs. Membrane materials can be 
divided into two main categories: organic polymers and inorganic membranes. Table 1 summarizes the membrane types, pore sizes, and other properties commonly found in AnMBRs. Organic polymer membranes are produced from readily available materials, and mainly include polyethersulfone (PES), polytetrafluoroethylene (PTFE), and polyvinylidene fluoride (PVDF). PVDF and PES have made up 75\% of the film market over the past few decades due to their excellent thermal stability, resistance to acid and alkali corrosion, and significant mechanical properties [2][27]. Recently, PTFE materials with higher membrane flux and better fouling resistance have been increasingly used as membrane materials, as membranes with thinner fibrous mesh pores have stronger adsorption properties and are less affected by irreversible contamination over the long term [28] [29]. In addition, polymeric materials such as polyethylene(PE) [30], polypropylene (PP) [31] [32], and polysulfone (PSF) [33] [34] have been used as anaerobic bioreactor membranes. Inorganic membranes can be divided into metal, alloy, ceramic, and glass membranes, among which ceramic and metal membranes are the main types of inorganic membranes. Compared to organic polymer membranes, metal membranes have good plasticity, toughness, and strength, and are well-suited to harsh environments [35] [36]. Ceramic membranes, however, have advantages such as high mechanical strength, corrosion resistance, and high membrane flux. Furthermore, the superhydrophilic nature of ceramic membranes can effectively mitigate membrane contamination by hydrophilic-hydrophobic repulsion, as determined based on a comparative analysis of filtration and treatment performance of polyvinylidene fluoride with ceramic membranes [37]. However, most currently 
132

133

commercialized ceramic membranes use expensive materials such as alumina, titanium dioxide, and silicon carbide, which limits their large-scale application. AnMBR effluents can be obtained by microfiltration (MF) or ultrafiltration (UF), and there are three general membrane module installation types: plate-andframe/plate (FS), hollow fiber (HF), and multi-tube (MT)[38] [39], where the membrane module installation is selected based on the influent flow rate and anaerobic sludge particle size [40]. A comparison of flat, hollow fiber, and tubular membranes is shown in Table 2 [41].

Flat membranes, which have high stability, and are easy to clean and replace, have recently attracted attention from many groups [38] [42][46]. Tubular membranes are composed of multiple tubular membranes, which are arranged in a tubular pattern, and have certain advantages over other membrane types, such as their low component pressure loss, high filtration efficiency, high fouling resistance, and they are easy to clean. However, the high operation and maintenance costs of flat and tubular membranes limits their large-scale commercial application [47], [48]. Furthermore, compared to flat and tubular membranes, hollow fiber membranes are most widely used in AnMBRs due to their high loading densities and high output efficiencies[38] [49].

\section{Reactor Performance}

\subsection{COD Removal Effect}


153 Early anaerobic processes were mainly used to treat industrial wastewater or highly154 concentrated organic wastewater, and have been rarely used to treat municipal 155 wastewater[50], for several reasons. For example, controlling the hydraulic retention 156 time reduces the process volume due to the high volume of domestic wastewater 157 However, shorter hydraulic retention times can lead to a loss of anaerobic 158 microorganisms, and the effluent water quality means that it cannot be reused for 159 human consumption [38] [51]. Recently, AnMBRs have become increasingly popular 160 for municipal wastewater treatment, as they can solve these problems. Table 3 shows 161 the operating conditions and treatment performance of an AnMBR for municipal 162 wastewater treatment, where the COD influent concentration was in the range of 110 $163860 \mathrm{mg} / \mathrm{L}$, and the hydraulic retention time was approximately $2.2-48 \mathrm{~h}$. When the 164 influent COD concentration of municipal wastewater is high (> $500 \mathrm{mg} / \mathrm{L})$, the 165 hydraulic retention time is generally greater than $10 \mathrm{~h} \mathrm{[12]} \mathrm{[52].} \mathrm{The} \mathrm{longest} \mathrm{hydraulic}$ retention time for this configuration is $48 \mathrm{~h}$, while the shortest hydraulic retention

167 time is $2.2 \mathrm{~h}$. In addition, the maximum organic loading rate (OLR) for this 168 configuration ranged from $3.77-4.97 \mathrm{~kg} \mathrm{COD} /\left(\mathrm{m}^{3} / \mathrm{d}\right)$, while the minimum OLR for 169 this configuration ranged from $0.16-1.95 \mathrm{~kg} \mathrm{COD} /\left(\mathrm{m}^{3} / \mathrm{d}\right)$. Municipal domestic wastewater temperature varies with climate, and the water 171 temperature can drop to as little as $5-10^{\circ} \mathrm{C}$ during winter [53]. Temperature is an 172 important factor that affects anaerobic microorganism activity, which in turn affects 173 the removal rate of organic matter during anaerobic digestion [23] [54] [55], sludge 174 production, and membrane contamination [56]. Microorganisms respond to a decrease 
175 in temperature by exhibiting self-protective behavior, including the release of soluble 176 microbial products and extracellular polymers, and as a result, lower temperatures can

177 lead to higher membrane contamination [55]. Ho and Sung [54] compared the 178 operational performance of two AnMBRs with synthetic municipal wastewater as 179 feedstock at operating conditions of $15^{\circ} \mathrm{C}$ and $25^{\circ} \mathrm{C}$, respectively. The COD removal 180 rate was greater than $95 \%$ at $25^{\circ} \mathrm{C}$, while the COD removal rate was only $85 \%$ at $18115^{\circ} \mathrm{C}$, indicating the same trend for specific methanogenic activity. Watanabe et al. 182 [55] increased pore plugging from $17 \%$ to $45 \%$ and transmembrane pressure (TMP) 183 increased from 0.1701 to $0.7231 \mathrm{kPa} / \mathrm{d}$ when the operating temperature decreased 184 from $25^{\circ} \mathrm{C}$ to $15^{\circ} \mathrm{C}$. Shin et al. [69] studied a pilot-stage anaerobic fluidized 185 membrane bioreactor (SAF-AnMBR) for more than six months, and found that 186 membrane contamination was more severe in winter under ambient temperature (8$\left.18730^{\circ} \mathrm{C}\right)$ using TMP as an indicator. Activated carbon (GAC) and ferric chloride $\left(\mathrm{FeCl}_{3}\right)$ 188 can also be added to resolve some of the issues related to the poor performance of 189 AnMBRs at low temperatures, as well as serious membrane pollution. Yoo et al. [68] 190 used GAC to dose a graded anaerobic fluidized membrane bioreactor (SAF-MBR), 191 and treated municipal domestic wastewater at $10-25^{\circ} \mathrm{C}$, achieving more than $89 \%$ 192 COD removal with a hydraulic retention time of $2.3 \mathrm{~h}$. The researchers speculated that 193 the high COD removal rate at low temperatures was related to the formation of a 194 biofilm on the surface of the activated carbon and membranes [12]. Dong et al. [72] 195 increased the COD removal rate from $79.9 \%$ to $93.7 \%$ with the addition of $\mathrm{FeCl}_{3}$ as a 196 coagulant. However, the addition of $\mathrm{FeCl}_{3}$ also caused an increase in sludge 
concentration and a decrease in methane production. Seib et al. (2016a) [66] ran four different AnMBR configurations at $10^{\circ} \mathrm{C}$ and $25^{\circ} \mathrm{C}$, in which all of the reactors were treated with synthetic wastewater first for the first 320 days. After this priming period, the reactors began treating municipal wastewater, and all four AnMBRs achieved more than 94\% COD removal for both synthetic and actual wastewater. Chen et al. (2017a) [63] compared the performance of a side-flow granular AnMBR with a submerged granular AnMBR in a laboratory setting at $25^{\circ} \mathrm{C}$. Both systems exhibited similar COD removal efficiencies (> 91\%), although the submerged granular AnMBR accumulated volatile fatty acids.

Therefore, regardless of the AnMBR type, the configuration, or the membrane characteristics, AnMBRs have good COD removal rates using municipal biological wastewater in laboratory or pilot settings. However, most AnMBR systems operate at $25^{\circ} \mathrm{C}\left(17-35^{\circ} \mathrm{C}\right)$ or room temperature, and in many temperate or cold regions, the temperature fluctuates significantly. In the face of the increasing energy crisis, the study of AnMBR for domestic wastewater treatment at low temperatures is of particular importance, especially for temperate and cold regions. Smith [64] showed that the COD removal rate of an anaerobic membrane bioreactor could reach more than $95 \%$ at $6^{\circ} \mathrm{C}$, but decreased to $86 \%$ at $3{ }^{\circ} \mathrm{C}$. The decrease in dissolved COD content in the sludge mixture indicated a decrease in microbial activity. The high COD removal rate at low temperatures in the reactor was attributed to the biofilm effect on the surface of the membrane module. Although the start-up period of the anaerobic membrane bioreactor at low temperatures is longer and the treatment effect 
and gas production is lower compared to medium temperature conditions $\left(33-35^{\circ} \mathrm{C}\right)$, the electrical energy consumption required to operate the anaerobic membrane bioreactor is also relatively lower.

Therefore, additional research is needed to address temperature and energy consumption issues, to promote the widespread applications of AnMBRs. The adverse effects of low temperatures on the AnMBR can be compensated for by extending the hydraulic residence time, but also by increasing the operating costs if the residence time is too long. To solve these problems, the shortcomings of low temperature operation can be compensated for by developing new membrane modules, improving start-up operation at low temperatures and using the biogas produced for reactor warming.

\subsection{Methane Production}

Biogas is a mixture of gases that are produced by the biological decomposition of organic matter under anaerobic conditions, and typically consists of methane $\left(\mathrm{CH}_{4}\right)$, hydrogen $\left(\mathrm{H}_{2}\right)$, carbon dioxide $\left(\mathrm{CO}_{2}\right)$, and nitrogen $\left(\mathrm{N}_{2}\right)$. Generally, methane accounts for $40-90 \%$ of biogas content, and under optimal conditions, energy output/input can reach $28.8 \mathrm{MJ} / \mathrm{mol}$, which would efficiently utilize this biomass energy and help to alleviate the global energy crisis [23] [38] [74] [78] [79]. As shown in Table 4, biogas and methane production varies greatly depending on the reactor type. Methane yield is typically in the range of $0.08-0.338 \mathrm{~L} \mathrm{CH}_{4} / \mathrm{g}$ COD. However, the theoretical value of methane yield is $0.382 \mathrm{~L} \mathrm{CH}_{4} / \mathrm{g} \mathrm{COD}\left(25^{\circ} \mathrm{C}\right)$ [38]. In practice, methane is partially 
241

dissolved in water[80]; therefore, the presence of inhibitors may inhibit anaerobic reactions [81], leading to actual biogas yields that are much lower than theoretical values. Inhibitors are substances that inhibit the metabolic activity of microorganisms in the anaerobic digestion process. Wastewater often contains toxic inhibitors and a wide variety of them, including ammonia, sulphides, heavy metals, salts, etc. They mainly reduce or even inhibit the metabolic action of methanogenic bacteria by affecting the activity of their enzymes, and the inhibition is usually manifested by a decrease in methane production rate and the accumulation of organic acids [81]. During AnMBR treatment, the sustainable OLR for reactors is subjected to the activity of bulk sludge, the activity of bulk sludge also acts on OLR in turn, $\mathrm{CH} 4$ yield will increase linearly with organic loading rate (OLR) [82], so a proper OLR is of great significance for an efficient methane conversion rate [23]. As shown in Fig. 3, there is a good linear relationship between OLR and methane production regardless of reactor structure, influent COD concentration, ambient temperature, and sludge concentration, which indicates that OLR is the main limiting parameter for methane production [23].

Dissolved methane in effluent can cause two problems. First, it reduces the methane yield of an AnMBR and affects the energy efficiency of the reactor, and second, methane is a greenhouse gas, and contributes significantly to global warming, especially as the greenhouse impact of $\mathrm{CH}_{4}$ is 25 times greater than the impact of $\mathrm{CO}_{2}$ [83]. Therefore, minimizing and recovering dissolved methane in wastewater is a 
critical requirement for the large-scale application of AnMBRs in municipal wastewater treatment.

Methods used to treat dissolved methane include membrane separation, aeration, and blowdown [84][87], among which membrane separation is the most effective method for recovering dissolved methane [85] [88]. Cookney et al. [89] found that more than $99 \%$ of dissolved methane could be recovered from anaerobic effluent using a hollow fiber membrane contactor system. However, the recovery of dissolved methane from anaerobic wastewater by membrane separation is still in the proof of concept stage, and its economic feasibility and process safety have not been fully evaluated. Therefore, in-depth studies on the membrane separation of dissolved methane for methane recovery have received significant attention from researchers as of late.

\section{Membrane Fouling Issues}

Membrane fouling is a key challenge that limits the applications of AnMBRs in municipal wastewater treatment, and one of the main reasons why membrane bioreactors cannot be widely used on an industrial scale. Membrane fouling refers to the phenomenon where colloids, suspended solids, sludge flocs, dissolved organic matter [90] [91], and other particles in wastewater are adsorbed and deposited on a membrane surface and block membrane pores, eventually causing decreased membrane flux [2] [92]. Considering the various pollutants that contribute to membrane fouling, membrane fouling mechanisms include membrane pore clogging, 
gel layer clogging, and cake clogging [48]. The common membrane fouling mechanisms affecting AnMBRs are shown in Fig. 4.

Membrane pore clogging occurs via membrane pore blockages, which mainly occurs during the initial stage of filtration [93] [94]. In membrane pore clogging, small particle sizes (smaller than the membrane pore size) will deposit in the membrane pores during filtration, eventually clogging the membrane pore. The main contaminants that cause membrane pore blockage include macromolecular organics and colloids, and these pollutants cannot be completely removed by physical cleaning, thus causing irreversible pollution [2] [95].

In gel layer blockage, a dense colloidal substance forms on the surface of the fouling layer close to the membrane, which is called the gel layer. This process forms via complexation reactions involving dissolved organic matter and metal ions during the filtration process [96].

In cake clogging, solid substances with larger particle sizes (larger than the membrane pore size) accumulate on the membrane surface during filtration, forming a cake layer after enrichment and concentration [2]. In AnMBRs, the large particles that form a cake layer mainly consist of sludge flocs [97], and sludge properties (including electrification, hydrophobicity, and EPS concentration) directly affect sludge aggregation in the mixture, as well as the formation of the cake layer [98]. The mud cake layer can be easily removed by backwashing and aeration, which causes shearing forces due to the large particle size, porosity, and the low viscosity of the filter cake layer. Therefore, filter cake clogging is considered a type of reversible pollution. 
Membrane contamination can reduce membrane flux when an AnMBR is operated at a constant pressure. However, membrane contamination can cause an increase in differential pressure across the membrane, especially when an AnMBR is operated at a constant flow. A three-stage trans-membrane pressure (TMP) curve can signify constant-flow operating conditions [48] [99][100]. In stage one, a rapid rise in TMP is typically observed at the beginning of a run (pore plugging). In stage two, a slow increase occurs in TMP (gel layer plugging), and stage three is known as the late TMP surge (cake plugging) (Fig. 4). Various hypotheses exist regarding the formation of stage three, all of which are consistent with the self-acceleration of membrane contamination at a constant flow rate, while some suggest that the stage three TMP jump is related to membrane surface contamination or an uneven distribution in membrane pore blockage. Furthermore, a larger drop in membrane flux may signify a more heavily contaminated local area. Therefore, to maintain a constant flow state, the flux in some areas of the membrane surface will operate at higher than critical flux, resulting in accelerated deposition of sludge floc particles [38] [48] [101][103]. Other researchers have suggested that the TMP jump is related to microorganism activity at the bottom of the membrane surface, and bacterial death may release a large amount of EPS and SMP [87], causing the TMP jump [104]. As membrane fouling is a very complicated process, a combination of these explanations may provide more accurate assessments what is occurring during fouling [38].

\subsection{Membrane Fouling Classification}


328 Membrane fouling can be classified according to contaminant composition as 329 biological, organic, or inorganic [90][93].

\subsubsection{Biological fouling}

Biological fouling, also known as biofilm fouling, occurs when bacteria or bacterial colloids produce a biofilm that is adsorbed on a membrane surface through proliferation and metabolism, and this is the main cause of membrane filtration performance degradation [90]. Large-sized sludge flocs are intercepted by the membrane and adsorbed on the surface, resulting in serious membrane fouling, which affects normal AnMBR operations [105]. Biological fouling is a two-step process, starting with initial bacterial attachment and followed by bacterial proliferation and metabolism on a membrane surface [106].

\subsubsection{Organic fouling}

342 Organic fouling is mainly caused by the metabolic products of microorganisms, which can adsorb on a membrane surface, forming a gel layer or deposit in membrane pores;

344 thereby causing blockages or membrane fouling. Extracellular polymers (EPS) and 345 soluble microbial products (SMP) are the main components that lead to organic 346 fouling [107][112]. Due to their small size, these organic products can easily deposit 347 on membrane surfaces and within membrane pores, resulting in organic fouling that is more difficult to remove than biological fouling [113]. 


\subsubsection{Inorganic fouling}

Inorganic fouling is the deposition of inorganic substances on a membrane surface or along the inner wall of membrane pores, through chemical precipitation or bioprecipitation. This process results in membrane pore occlusion or pore blockages, and causes a decrease in membrane flux [2] [48]. Chemical precipitation mainly occurs due to concentrated polarization, and bioprecipitation is mainly caused by metallic ions, which act as bridges between the deposited microorganisms and organic polymers, forming a dense filter cake layer [114]. Ions related to inorganic fouling include $\mathrm{Ca}^{2+}, \mathrm{Mg}^{2+}, \mathrm{Fe}^{3+}, \mathrm{Al}^{3+}, \mathrm{SO}_{4}{ }^{2-}, \mathrm{PO}_{4}{ }^{3-}, \mathrm{CO}_{3}{ }^{2-}$, and $\mathrm{OH}^{-}$plasma [48] [115] [116]. Furthermore, at appropriate concentrations, metallic ions, such as $\mathrm{Ca}^{2+}$, will combine and bridge with extracellular polymers and soluble microbial products, increasing the floc size. This can effectively reduce the deposition of organic fouling on membrane surfaces, but excessive metal ion concentrations can also aggravate inorganic fouling [117]. Hence, to remove inorganic contamination deposits on membrane surfaces, the surfaces must be chemically cleaned.

\subsection{Factors that Affect Membrane Fouling in AnMBRs}

Many factors can influence membrane fouling, and these can be broadly classified according to membrane characteristics, operating conditions, and sludge properties, as shown in Fig. S1.

\subsubsection{Sludge properties}


372 Mixed liquid suspended solids (MLSS) significantly affect membrane flux, as the 373 higher the MLSS concentration, the faster the membrane fouling rate [118]. A higher 374 MLSS concentration results in increased deposition of colloids, sludge flocs, 375 macromolecules, and microbial products on membrane surfaces [1]. $\mathrm{Wu}$ and Huang [119] reported that AnMBRs operating at MLSS concentrations above $10,000 \mathrm{mg} / \mathrm{L}$ deal with increased sludge viscosity, and membrane permeability decreases with increasing sludge viscosity. Therefore, EPS and SMP are the most significant factors that contribute to membrane fouling compared to other sludge characteristics (such as MLSS, sludge particle size, and sludge viscosity)[107][109]. Due to the deposition and adsorption of EPS and SMP on membrane surfaces or pores, faster Brownian diffusion of liquid will occur [1] [107] [120]. This also causes the formation of a gel contamination layer, which can significantly increase membrane filtration resistance.

\subsubsection{Operation conditions}

The mode of operation is closely related to the membrane fouling rate, and in AnMBRs, there are two modes of operation: constant pressure and constant flux (constant flow) operations [48]. AnMBRs are commonly operated in constant flux

390 mode, as they better handle fluctuations in influent hydraulic load [121]. In addition,

391 the flux is critical to the long-term stability of the membrane, and operating at a 392 higher flux will accelerate the formation of a filter cake layer. However, low temperatures and an increase in organic loading can promote the release of EPS, 
resulting in faster membrane contamination rates [122] [123]. Hydraulic retention time (HRT) and sludge retention time (SRT) can also influence membrane contamination by changing the nature of the sludge mix in a reactor [48]. Furthermore, longer SRTs can cause an increase in sludge concentration and the release large amounts of EPS due to the decomposition of dead cells, resulting in faster membrane fouling rates [120]. Although a shorter HRT can increase the sludge growth rate and effluent treatment efficiency, it can also cause an increase in sludge concentration and increased membrane fouling [124].

\subsubsection{Membrane properties}

Membrane properties such as membrane surface morphology (roughness), hydrophilicity/hydrophobicity, surface charges, and membrane pore size, can have varying degrees of influence on membrane fouling [1] [125]. Membrane fouling can be more severe with hydrophobic membranes than for hydrophilic membranes, due to hydrophobic interactions between membrane materials, microorganisms, and solutes [97][99] [107]. Membrane surface roughness and surface charges will have a greater impact on membrane fouling, as opposed to hydrophilicity/hydrophobicity. Thus, the greater the membrane surface roughness, the greater the specific surface area of a corresponding membrane, although more contaminants will be adsorbed on the membrane surface. However, the increased roughness will also increase the degree of hydrodynamic disturbance on a membrane surface, which will hinder the adsorption and deposition of contaminants on a membrane surface and thus delay membrane 
fouling [126]. In addition, colloidal particles in aqueous solutions are generally negatively charged, and using membrane materials with the same charges as the solute in a mixture can improve and alleviate membrane fouling via electrostatic repulsions, thus improving membrane flux. As a result, choosing membrane materials with a certain degree of roughness may result in negative potential membrane fouling that will be relatively minimal [125]. The pore size of a membrane can also significantly affect membrane fouling, with larger pore sizes having higher fouling rates compared to smaller pore sizes. In general, AnMBRs use membranes with pore sizes of $0.02-0.5 \mu \mathrm{m}[127]$.

\subsection{Controlling Membrane Fouling}

Membrane fouling is inevitable in practical applications, and therefore, strategies to control or mitigate membrane fouling are important to the operation of a reactor and to address the causes and mechanisms of membrane fouling. Based on the factors that affect membrane fouling, control strategies can be divided into the following categories.

\subsubsection{Membrane cleaning}

Depending on the reversibility of membrane fouling, or the degree to which membrane fouling can be removed, membrane module cleaning can be divided into either physical or chemical cleaning. Physical cleaning methods mainly focus on removing reversible contamination, and the main physical cleaning methods include 
isobaric rinsing, backwashing, gas-liquid mixture shock cleaning, negative pressure cleaning, mechanical scraping, and electric cleaning [38] [128]. Recently, controlling membrane fouling by applying shear forces via biogas injection has been widely studied and applied, especially for particle injection and rotating membranes [1] [12][52]. Evans et al. [61] tested the performance of biogas injection for controlling membrane fouling in AnMBRs and found a decrease in membrane surface fouling and an increase in membrane permeability at higher injection rates. Particle jet membrane bioreactors, also known as anaerobic fluidized bed membrane bioreactors, consist of fluidized granular activated carbon (GAC). These solutions not only offer a scouring effect on the membrane surface in the form of a scouring agent, but also provide a location for microbial growth [129][131]. Compared to biogas jet reactors, particle jet reactors have relatively low energy consumption and can control membrane fouling well [131][134]. The rotating membrane creates turbulent flow on the membrane surface through the rotation of the membrane module itself, which slows down the formation of the pollution layer on the membrane surface. Additionally, rotating the membrane module can agitate the sludge mixture. Although a rotating membrane module was designed by Belford et al. [135] 28 years ago, this method has attracted extensive attention from researchers in recent years due to its low energy consumption [136]. One advantage of physical cleaning is that cleaning is simple, no new pollutants are introduced, and the likelihood of chemical damage to the membrane is low. However, the physical cleaning method is only effective for the membrane modules during the initial pollution stage, and the cleaning effect does not last long. 
461

462

473 [38]. However, frequent exposure to chemical reagents will compromise membrane 474 integrity and alter membrane surface properties [141], which will affect normal 475 membrane filtration behavior. Therefore, a combination of physical and chemical 476 cleaning is an effective strategy for mitigating membrane fouling.

478 4.3.2. Membrane material selection and membrane modification

479 Hydrophilic modification of the membrane surface is a common strategy for 480 controlling membrane fouling in AnMBRs [142] [143]. Currently, polar organic 481 functional groups on membrane surfaces can be modified by plasma treatment, 
surface grafting, surface coating, or surface blending. Plasma treatment forms hydrophilic functional groups on a membrane surface [144]. As an example, Yu et al. used plasma technology to modify the surfaces of polypropylene membranes, and found that $\mathrm{NH}_{3}$ and $\mathrm{CO}_{2}$ plasma-treated membranes exhibited a significant increase in hydrophilicity. Furthermore, the newly modified membranes had better filtration and flux recovery performance than unmodified membranes [145] [146]. Surface polymer grafting is also an effective method to improve membrane hydrophilicity. By grafting and polymerizing methoxypolyethylene glycol on the surface of polypropylene membranes, Wang et al. observed that with increased grafting degree, the flux of the modified membrane was twice that of an unmodified membrane [147]. Surface coatings are also a surface modification method, and $\mathrm{Pi}$ et al. demonstrated that $\mathrm{TiO}_{2}$ nanoparticles can improve the surface wettability and permeability properties of hydrophobic membranes, specifically when $\mathrm{TiO}_{2}$ was loaded onto the polypropylene microfiltration membrane surfaces using the sol-gel method [148].

The use of engineered nanomaterials (ENMs) as membrane materials has become an area of recent intense research. Engineered nanomaterials, including metal oxide-based nanomaterials, carbon nanomaterials, and silver nanoparticles, which have good antibacterial and hydrophilic properties, may offer great benefits in alleviating membrane fouling, especially biological fouling [149]. 
503

504

505

506

507

508

509

510

511

512

513

Optimizing AnMBR operating parameters is essential for controlling membrane fouling, with key operating parameters including hydrodynamic conditions, membrane flux, HRT, SRT, MLSS, pH, and temperature [2] [38]. Increasing the intensity and duration of gas flushing in submerged AnMBRs, as well as the flow rate of mixed liquids in sidestream-AnMBRs, can provide the optimal hydrodynamic conditions to mitigate membrane fouling. An important strategy for mitigating membrane fouling involves membrane filtration at a filtration flux below the critical flux. Thus, when the filtration flux is below the critical flux, membrane fouling is less severe. However, when the filtration membrane flux is above the critical flux, more severe membrane fouling can be observed [150]. In addition, recent results indicate that the operating parameters greatly affect the metabolism of microorganisms, especially the release of SMP. Longer SRTs can promote the complete degradation of solid matter, but will reduce floc size, and increase the sludge and SMP concentration, which can cause increased membrane fouling [128]. Shorter HRTs can reduce the reactor volume, but will result in insufficient metabolism of organic matter, and higher organic matter concentrations also aggravate membrane fouling [151] [152].

\subsubsection{Regulation of sludge mixture characteristics}

Currently, the most direct and effective way to improve sludge mixture characteristics involves the use of additives, such as adsorbents and flocculants [38]. In AnMBRs, adsorbents will adsorb colloids and dissolve organic compounds in the sludge mixture, which reduces membrane fouling. Powdered activated carbon (PAC) is a widely used 
525

adsorbent in AnMBRs, and PAC addition can control scaling, including dirt adsorption and its subsequent biodegradation, as well as increase the critical flux, improve the strength of microbial flocs, and enhance the scouring effect of particles on membrane surfaces. In 1999, it was reported for the first time that PAC can reduce fouling in membrane bioreactors, and the results showed that as the PAC dosage increased to $5 \mathrm{~g} / \mathrm{L}$, the fouling resistance and filter cake resistance continued to decrease. In addition, PAC provides a carrier for the growth of microorganisms, avoiding the rupture of sludge flocs under the action of hydraulic shear. However, the adsorption capacity of activated carbon is limited, and therefore, the saturated portion needs to be discharged during operation and newly activated carbon must be simultaneously added [153]. Unfortunately, excessive PAC can also increase membrane fouling, as excessive PAC can act as a pollutant [154] [155]. Other adsorbents such as zeolite, bentonite, and vermiculite can also be used to reduce membrane fouling [156]. Coagulant addition is also an effective strategy for controlling membrane fouling. Commonly used flocculants include iron salts $\left(\mathrm{FeSO}_{4}\right.$ and $\mathrm{FeCl}_{3}$ ), aluminum salts $\left(\mathrm{AlCl}_{3}\right)$, inorganic polymers (polyferric sulfate and polyaluminum chloride), and organic polymers (such as starch and chitosan). Flocculant addition can also increase the particle size of sludge and reduce the concentration of organic matter in the supernatant, thus reducing membrane fouling [157]. Zhang et al. [133] observed that the addition of ferric chloride increased floc particle size and reduced the dissolved organic matter in the supernatant, which alleviated membrane fouling. However, flocculant addition reduces the $\mathrm{pH}$ of the 
mixture, and a decrease in $\mathrm{pH}$ affects microorganism activity. In addition, excessive

548 flocculants can deposit on the membrane surface, which can aggravate membrane 549 fouling [48].

550

551

552

553

554

555

556

557 fouling and promote methane production [52]. As shown in Fig. S2(a), sludge loss can

558 be reduced by the interception of the membrane. However, an electrical bias needs to

559 be applied to the membrane surface to generate electrochemical auxiliary conditions.

560 Membrane fouling can be alleviated by the electrostatic forces between pollutants and

561 the membrane surface, as well as the electro-flocculation between pollutants, the

562 electrochemical reactions on the membrane surfaces, and the scouring effect of the

563 gas produced by the electrode [158]. The introduction of an electric field stimulated

564 the growth and metabolism of electroactive microorganisms in the reaction zone and

565 electrode surface, which increased the population of hydrolytic acidifying and

566 methanogenic bacteria [159]. In addition, this also promoted the extracellular electron

567 transfer of anaerobic microorganisms between the electrodes. This enhanced the

568 transformation efficiency of the organic matter, intermediates, and cellular 
metabolites in anaerobic reactions, improving treatment efficiency and biogas yield. As a result, this method could recover energy from sewage via biogas production, while also reducing energy consumption.

Yang et al. [160] designed a new type of conductive carbon nanotube hollow fiber membrane (CNT-HFMs) as an AnMBR, in which the CNT-HFMs had dual functions as cathodes and membrane filters. Compared to conventional AnMBRs, and CNT-HFM AnMBRs without voltage, the transmembrane pressure differential rate of this new type of anaerobic electrochemical membrane bioreactor increased slowly throughout the nearly 100 day operation period, and the COD removal rate in the effluent reached more than $95 \%$, due to the actions of the electrical field. In addition, negatively charged membrane fouling substances (including microorganisms and their secretions) moved away from the membrane surface. This reduced membrane pore blockage in the anaerobic electrochemical membrane bioreactor, and the application of the electric field effectively improved microorganism activity in the mixture and improved COD removal efficiency. Katuri et al. [161] also used atomic layer deposition (ALD) to deposit platinum on a metal catalyst. On the porous skeleton membrane surface, the researchers used a biological cathode and a carbon fiber brush as an anode, to study the performance of this new anaerobic electrochemical membrane bioreactor. The experimental results showed that the COD removal rate of simulated domestic sewage was more than $95 \%$ under a voltage of $1.0 \mathrm{~V}$, and the COD removal rate of actual wastewater reached $83 \%$. In addition, membrane fouling was well alleviated, and TMP after long term operation was only $1 / 3$ of the control 
591 group. However, the magnitude of the applied voltage had to be reasonably regulated 592 according to the experimental conditions, purpose, and raw water quality, to achieve 593 better sewage treatment effect and minimize membrane fouling.

594

595

\subsection{Anaerobic Dynamic Membrane Bioreactors (AnDMBRs)}

596

597 598

599

600

601

602

603

604

605

606

607

608

609

610

611

612

Dynamic membranes were first reported by Oak Ridge National Laboratory in the

United States in the early 1960s. When conducting seawater desalination experiment, the researchers found that a physical dynamic zirconia membrane with reverse osmosis would form when the porous material was exposed to a specific solution [162] [163]. The dynamic membrane bioreactor was intercepted by cheap coarse porous filter substrates, such as non-woven cloth, and solid-liquid separation performance was similar to microfiltration and ultrafiltration membranes, when a sludge layer (dynamic membrane) was attached to the filter membrane module [164]. The application of a dynamic membrane to an aerobic membrane bioreactor was also assessed in the early 2000s. Currently, AeDMBRs have developed into a relatively mature technology. However, the application of dynamic membranes for AnMBRs is still developing, and was first proposed by David Jeison et al. in 2008, which confirmed the feasibility of dynamic membranes for anaerobic bioreactors [165]. Compared to AnMBRs, the coarse porous filter material in AnDMBRs replaces the traditional microfiltration/ultrafiltration membrane, greatly reducing the initial cost (Fig. S2(b)).Secondly, the dynamic membrane that forms on the coarse porous filter material can be regenerated in situ and recycled, without requiring frequent cleaning 
613

614

615

617

618

619

620

621

622

623

624

625

626

627

628

629

630

631

632

633

634

or replacement of expensive membrane components, giving it better removal performance for pollutants in water (60-90\% COD removal rate, 90-100\% turbidity, and suspended solids removal rate). Li et al. [166] used a stainless-steel mesh with a pore diameter of $40 \mu \mathrm{m}$ as a filter material to conduct a study on the treatment of low concentration domestic sewage using an AnDMBR. The results showed that the removal efficiency of COD was more than $90 \%$, and the methane yield was $0.24 \mathrm{~L}$

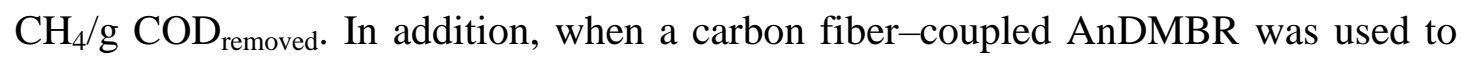
treat the wastewater with different organic loads $\left(0.46-17 \mathrm{~kg} \mathrm{COD} /\left(\mathrm{m}^{3} \mathrm{~d}\right)\right)$, satisfactory and stable process performance was achieved. The COD removal efficiency was $95 \%$ and the methane yield was $0.29 \mathrm{~L} \mathrm{CH}_{4} / \mathrm{g} \mathrm{COD}_{\text {removed. Alibardi et }}$ al. [167] used an external AnDMBR with a $200 \mu \mathrm{m}$ aperture grid to treat low concentration wastewater, and the average total COD and soluble COD removal efficiencies were higher than $80 \%$ and $90 \%$, respectively. Ersahin et al. [168]studied the effect of AnDMBR configuration (immersion type and external type) on the treatment and filtration performance, and found that both devices achieved high COD removal rates of more than $90 \%$. Further studies showed that submerged AnDMBR had a faster start-up time, better effluent quality, and higher biogas production than other types of AnMBRs.

\subsection{Anaerobic Osmotic Membrane Bioreactors (AnOMBRs)}

Forward osmosis (FO) refers to the transport of water from areas of higher hydration potential to areas with lower hydro-chemical potential, using selective osmosis 
635

636

637

membranes. This process is driven by the solute concentration differences on both sides of the membrane, and selective permeation membrane allows for the water molecules to pass through, while repelling most solute molecules or ions [169]. AnOMBR introduces forward osmosis into an AnMBR. Under the action of osmotic pressure differences between the mixture and suction, most of the water molecules in sewage will spontaneously enter the absorption liquid through an FO membrane, and pollutants will be intercepted by the FO membrane in the reactor, thus concentrating the wastewater [170]. In contrast to a conventional AnMBR, the AnOMBR membrane filtration process does not require any energy input (Fig. S2(c)). Chen et al. [171] treated domestic sewage with an AnOMBR at $25^{\circ} \mathrm{C}$ and found that the COD, ammonia nitrogen, and total phosphorus removal rates in the reactor were 96, 62, and $100 \%$, respectively. In addition, the treatment effectiveness was much higher than for conventional AnMBRs, and the methane yield of the reactor was approximately 0.21

$\mathrm{L} \mathrm{CH}_{4} / \mathrm{g} \mathrm{COD}_{\text {removed. }}$ Although a portion of the methane was dissolved in the mixture and entered the absorption solution, resulting in a methane yield of only $58-76 \%$ of the maximum theoretical value, the methane production rate was still much higher than conventional AnMBRs. Gao et al. [172] studied the treatment effect of an AnOMBR on urban domestic sewage using different concentrations of extracted solutions ( $\mathrm{NaCl}$ solution). The results showed that this type of reactor was effective in treating municipal domestic sewage under different working conditions, and the removal rates of $\mathrm{COD}, \mathrm{NH}_{4}{ }^{+}-\mathrm{N}, \mathrm{TN}$, and TP were $96 \%, 88 \%, 89 \%$, and nearly $100 \%$, respectively. Although AnOMBRs have shown excellent performance in treating 
domestic wastewater, enriched solutes in domestic sewage and salt solute back mixing of an FO membrane can cause salt accumulation in this type of reactor, which adversely affects the membrane flux and microbial activity. Therefore, reducing salt accumulation in an AnOMBR reactor should be studied in the future.

\subsection{Anaerobic Membrane Distillation Bioreactors (AnMDBRs)}

Membrane distillation is a membrane process where the vapor pressure difference produced by the temperature gradient on both sides of the hydrophobic microporous membrane is used to power a separation effect [173] [174]. Anaerobic membrane distillation bioreactors (AnMDBRs) are a new type of AnMBR that specifically integrates membrane distillation into the AnMBR for wastewater treatment and reuse (Fig. S2(d)). According to the principles of membrane distillation, hydrophobic microporous membranes are used for mud-water separation, and mass transfer is the driving force in such an anaerobic membrane distillation bioreactor, in turn driven by the temperature differences between the two sides of the membrane. Through this temperature difference, water vapor evaporates through the membrane and the organic matter is intercepted to optimize effluent quality. Song et al. [175] used an anaerobic membrane distillation bioreactor to treat simulated highly concentrated domestic sewage. The removal rates of TOC and COD in this reactor were more than $98 \%$, the biogas yield was $0.3-0.5 \mathrm{~L} / \mathrm{g} \mathrm{COD}_{\text {added, }}$ and the methane content was stable at about 65\%. Furthermore, Kim et al. [176] coupled an anaerobic moving bed membrane bioreactor and membrane distillation to treat domestic sewage, and the COD and TP 
679

680

681

682

683

684

685

686

687

688

689

690

691

692

693

694

695

696 697 during the recovery process.

698

699

700

\section{Future Perspectives}

removal rates reached $92 \%$ and $100 \%$, and methane production accounted for approximately $58-72 \%$ of total biogas production using this bioreactor.

Over the past few decades, many scholars have investigated new techniques to mitigate membrane fouling and improve the performance of AnMBRs. Compared to conventional AnMBRs, coupled processes such as AnEMBRs, AnDMBRs, AnOMBRs, and AnMDBRs have higher pollutant removal rates, methane yields, and lower membrane fouling rates. However, these processes are still limited to the laboratory, and the membrane fouling control mechanisms and energy balance for treatment processing need to be studied further. In addition, the results of laboratoryscale studies should be validated on a large scale, and long-term studies need to be conducted for practical applications.

Another aspect that needs to be studied is the recovery of dissolved methane using AnMBRs with high efficiency and at a low cost. This process will require maximum production and minimum dissolution of methane at low temperatures (10$30^{\circ} \mathrm{C}$ ), the development of methane recovery technology, the design of methane recovery equipment, improved cost control, and more efficient energy consumption

In addition, to further solve reliability and large-scale commercial application issues for AnMBRs, breakthroughs need to be made in the following areas.

(1) Improvements in the performance of membrane materials and modules 
701 Develop and research new separation membranes with superior performance that are

702

703

704

705

706

707

708

709

710

711

712

713

714

715

716

717 not only pollution resistant, long-lasting and mechanically strong, but also chemically stable and inexpensive.

(2) Development of environmentally friendly membrane cleaning strategies

Development of green cleaning agents to minimise the impact of chemical cleaning on the membrane and microbial activity; research into new membrane cleaning strategies such as biological cleaning, ultrasonic cleaning, etc.

(3) Membrane contamination mechanism and prevention technology

Further in-depth research into the effects and mechanisms of membrane filtration and membrane contamination processes; develop more effective, easy-to-use methods to control and mitigate membrane contamination; establish effective contamination models for domestic wastewater to avoid long and costly tests.

(4) Optimisation of process flow and operating conditions of anaerobic membrane bioreactors

Optimisation is carried out in terms of both pollutant treatment effects and membrane pollution control to ensure both stable treatment effects and long operation of the AnMBR process. Specific studies include strengthening denitrification to improve nitrogen removal; reducing energy consumption during operation; studies on sludge retention control measures and time; and optimisation studies on the combination of membrane modules and new wastewater treatment technologies.

\section{Conclusions}


723 This review article summarized the recent progress in AnMBR technology for 724 wastewater treatment, offering a promising alternative to traditional wastewater 725 treatment technology with various application prospects. However, there are still 726 many challenges that limit the large-scale commercial applicability of AnMBRs.

727 Membrane fouling is the main obstacle for large-scale commercial AnMBR 728 applications, and membrane materials, membrane modules, sludge properties, and 729 operating conditions are the main factors that affect membrane fouling. In recent 730 years, many new types of AnMBRs have been developed to control membrane 731 fouling and have achieved satisfactory results in the lab. Therefore, future research 732 should focus on the following areas: First, these treatments need to be scaled to reach 733 a level that is suitable for practical applications. In addition, simpler and more 734 effective strategies to control membrane fouling control need to be developed. Finally, 735 the recovery of dissolved methane in water must be maximized and the energy 736 consumption during reactor operation must be reduced.

\section{Acknowledgments}

739 We thank the staff of the School of Energy and Environment, the Shenyang 740 University of Aeronautics and Astronautics and the Environmental Pollution Control 741 Research Center, and the Chinese Academy of Environmental Sciences for their 742 assistance. We acknowledge financial support from the National Key Research and Development Program of China (No. 2018YFD1100505). 
745

746

747

748

749

750

751

752

753

754

755

756

757 [1]Maaz M, Yasin M, Aslam M, et al. Anaerobic membrane bioreactors for wastewater

758 treatment: Novel configurations, fouling control and energy considerations.

759 Bioresour. Technol. 2019;283:358-372.

760 https://doi.org/10.1016/j.biortech.2019.03.061.

761 [2]Lei Z, Dzakpasu M, Li Q, Chen R. Current Developments in Biotechnology and

762 Bioengineering. Anaerobic membrane bioreactors for domestic wastewater

763 treatment. 2020. p.143-165. https://doi.org/10.1016/B978-0-12-819852-0.00006-3.

764 [3]Khan M, Ngo H, Guo W, Liu Y, Zhou J, Zhang J, Liang S, Ni B, Zhang X, Wang J.

765 Comparing the value of bioproducts from different stages of anaerobic membrane bioreactors. Bioresour. Technol. 2016;214:816-825. 
768 [4]Stuckey DC. Recent developments in anaerobic membrane reactors. Bioresour. 769 Technol. 2012;122:137-148. https://doi.org/10.1016/j.biortech.2012.05.138.

770 [5]Chen R, Jiang H, Li YY. Caffeine degradation by methanogenesis:efficiency in 771 anaerobic mem-brane bioreactor and analysis of kinetic behavior. Chem. Eng. J. 2018;334:444-452. https://doi.org/10.1016/j.cej.2017.10.052.

773 [6]Chen R, Wen W, Jiang H, Lei Z, Li M, Li YY. Energy recovery potential of 774 thermophilic high-solids co-digestion of coffee processing wastewater and waste 775 activated sludge by anaerobic membrane bioreactor. Bioresour. Technol. 2019;274:127-133. https://doi.org/10.1016/j.biortech.2018.11.080

777 [7]Ike M, Inoue D, Miyano T, et al. Microbial population dynamics during startup of a 778 full-scale anaerobic digester treating industrial food waste in Kyoto eco-energy 779 project. Bioresour. Technol. 2010;101:3952-3957.

780 https://doi.org/10.1016/j.biortech.2010.01.028.

781 [8]Yue XD, Koh YKK, Ng HY. Effects of dissolved organic matters (DOMs) on 782 membrane fouling in anaerobic ceramic membrane bioreactors (AnCMBRs) 783 treating domestic wastewater. Water Res. 2015;86:96-107. $784 \quad$ https://doi.org/10.1016/j.watres.2015.07.038.

785 [9]Giménez JB, Robles A, Carretero L, Durán F, Ruano MV, Gatti MN. Experimental 786 study of the anaerobic urban wastewater treatment in a submerged hollow-fibre membrane bioreactor at pilot scale. Bioresour. Technol. 2011;102:8799-8806. 
789 [10]Foglia A, Cipolletta G, Frison N, Sabbatini S, Gorbi S, Eusebi AL. Anaerobic 790 membrane bioreactor for urban wastewater valorisation:operative strategies and 791 fertigation reuse. Chem. Eng. Trans. 2019;74:247-252. $792 \quad$ https://doi.org/10.3303/CET1974042.

793 [11]Ozgun H, Gimenez JB, Mustafa EE, Tao Y, Spanjers H, Van Lier JB. Impact of 794 membrane addition for effluent extraction on the performance and sludge 795 characteristics of up flow anaerobic sludge blanket reactors treating municipal 796 wastewater. $\quad J . \quad$ Membr. $\quad S c i . \quad$ 2015;479:95-104. 797 https://doi.org/10.1016/j.memsci.2014.12.021.

798 [12]Shin C, Bae J. Current status of the pilot-scale anaerobic membrane bioreactor 799 treatments of domestic wastewaters:a critical review. Bioresour. Technol. $800 \quad$ 2018;247:1038-1046. https://doi.org/10.1016/j.biortech.2017.09.002.

801 [13]Fuwad A, Ryu H, Malmstadt N, Kim SM, Jeon TJ. Biomimetic membranes as 802 potential tools for water purification:preceding and future avenues. Desalination $803 \quad$ 2019b;458:97-115. https://doi.org/10.1016/j.desal.2019.02.003.

804 [14]Akram A, Stuckey DC. Flux and performance improvement in a submerged 805 anaerobic membrane bioreactor (SAMBR) using powdered activated carbon (PAC). 806 Process Biochem. 2008;43:93-102. https://doi.org/10.1016/j.procbio.2007.10.020

807 [15]Huang Z, Ong SL, Ng HY. Feasibility of submerged anaerobic membrane 808 bioreactor (SAMBR) for treatment of low-strength wastewater. Water Sci. Technol. 809 2008;58:1925-1931. https://doi.org/10.2166/wst.2008.749. 
810 [16]Van Zyl PJ, Wentzel MC, Ekama GA, Riedel KJ. Design and start-up of a high rate

811 anaerobic membrane bioreactor for the treatment of a low $\mathrm{pH}$, high-strength,

812 dissolved organic wastewater. Water Sci. Technol. 2008;57:291-295.

$813 \quad$ https://doi.org/10.2166/wst.2008.083.

814 [17]Zhang J, Padmasiri SI, Fitch M, Norddahl B, Raskin L, Morgenroth E. Influence of 815 cleaning frequency and membrane history on fouling in an anaerobic membrane bioreactor.

Desalination 2007;207:153-166. https://doi.org/10.1016/j.desal.2006.07.009

818 [18]Trzcinski AP, Stuckey DC. Anaerobic digestion of the organic fraction of municipal 819 solid waste in a two-stage membrane process. Water Sci. Technol. 2009;60:1965820 1978. https://doi.org/10.2166/wst.2009.498.

821 [19]Lin HJ, Xie K, Mahendran B, et al. Sludge properties and their effects on membrane 822 fouling in submerged anaerobic membrane bioreactors(SAnMBRs). Water Res. 823 2009;43:3827-3837. https://doi.org/10.1016/j.watres.2009.05.025

824 [20]Padmasiri IS, Zhang J, Fitch M, Norddahl B, Morgenroth E, Raskin L. 825 Methanogenic population dynamics and performance of an anaerobic membrane 826 bioreactor(AnMBR) treating swine manure under high shear conditions. Water Res. 827 2007;41:134-144. https://10.1016/j.watres.2006.09.021

828 [21]Szentgyörgyi E, Bélafi-Bakó K. Anaerobic membrane bioreactors. Hung. J. Indus. 829 Chem. Veszprem 2010;38(2):181-185. https://doi.org/10.1515/298.

830 [22]Conrad R. The global methane cycle:recent advances in understanding the microbial processes involved. Environ. Microbiol. Rep. 2009;1:285-292. 
833 [23]Lei Z, Yang S, Li Y, Wen W, Wang XC, Chen R. Application of anaerobic 834 membrane bioreactors to municipal wastewater treatment at ambient temperature:a 835 review of achievements, challenges, and perspectives. Bioresour. Technol. $836 \quad$ 2018;267:756-768. https://doi.org/10.1016/j.biortech.2018.07.050

837 [24]Jones WJ, Guyot JP, Wolfe RS. Methanogenesis from sucrose by defined 838 immobilized consortia. Appl Environ Microbiol. 1984;47:1-6.

839 https://doi.org/10.1128/AEM.47.1.1-6.1984

840 [25]Ketheesan B, Stuckey DC. Effects of hydraulic/organic shock/transient loads in 841 anaerobic wastewater treatment:a review. Crit. Rev. Environ. Sci. Technol. $842 \quad$ 2015;45:2693-2727. https://doi.org/10.1080/10643389.2015.1046771

843 [26]Xie Z, Wang Z, Wang Q, Zhu C, Wu Z. An anaerobic dynamic membrane 844 bioreactor (AnDMBR) for landfill leachate treatment:performance and microbial 845 community identification. Bioresour. Technol. 2014;161:29-39.

846 https://doi.org/10.1016/j.biortech.2014.03.014

847 [27]Santos A, Judd S. The commercial status of membrane bioreactors for municipal 848 wastewater. Sep. Sci. Technol. 2010;45:850-857. $849 \quad$ https://doi.org/10.1080/01496391003662337

850 [28]Fan H, Xiao K, Mu S, Zhou Y, Ma J, Wang X, Huang X. Impact of membrane pore 851 morphology on multi-cycle fouling and cleaning of hydrophobic and hydrophilic 852 membranes during MBR operation. J. Membr. Sci. 2018;556:312-320. 
854 [29]Lee EJ, Kim KY, Lee YS, et al. A study on the high-flux MBR system using PTFE 855 flat sheet membranes with chemical backwashing. Desalination 2012;306:35-40.

856 https://doi.org/10.1016/j.desal.2012.08.031

857 [30]Vyrides I, Stuckey DC. Saline sewage treatment using a submerged anaerobic 858 membrane reactor (SAMBR):effects of activated carbon addition and biogas859 sparging time. Water Res. 2009;43:933-942. $860 \quad$ https://doi.org/10.1016/j.watres.2008.11.054

861 [31]Sainbayar A, Kim JS, Jung WJ, Lee YS, Lee CH. Application of surface modified 862 polypropylene membranes to an anaerobic membrane bioreactor. Environ. Technol. 863 2001;22:1035-1042. https://doi.org/10.1080/09593332208618212

864 [32]Jeong E, Kim HW, Nam JY, Ahn YT, Shin HS. Effects of the hydraulic retention 865 time on the fouling characteristics of an anaerobic membrane bioreactor for treating 866 acidified wastewater. Desalin. Water Treat. 2010;18:251-256. $867 \quad$ https://doi.org/10.5004/dwt.2010.1781

868 [33]Jeison D, Van Betuw W, Van Lier JB. Feasibility of anaerobic membrane biore869 actors for the treatment of wastewaters with particulate organic matter. Sep. Sci. 870 Technol. 2008;43:3417-3431. https://doi.org/10.1080/01496390802221659.

871 [34]Vallero MVG, Lettinga G, Lens PNL. High rate sulfate reduction in a submerged 872 anaerobic membrane bioreactor (SAMBR) at high salinity. J. Membr. Sci. $873 \quad 2005 ; 253: 217-232$. https://doi.org/10.1016/j.memsci.2004.12.032. 
874 [35]Zhang S, Qu Y, Liu Y, et al. Experimental study of domestic sewage treatment with 875 a metal membrane bioreactor. Desalination 2005;177:83-93. 876 https://doi.org/10.1016/j.desal.2004.10.034.

877 [36]Kim JO, Jung JT. Performance of membrane-coupled organic acid fermentor for the 878 resources recovery form municipal sewage sludge. Water. Sci. Technol. $879 \quad 2007 ; 55: 245-252$. https://doi.org/10.2166/wst.2007.328.

880 [37]Jeong Y, Kim Y, Jin Y, Hong S, Park C. Comparison of filtration and treatment 881 performance between polymeric and ceramic membranes in anaerobic membrane 882 bioreactor treatment of domestic wastewater. Sep. Purif. Technol. 2018;199:182$883 \quad$ 188. https://doi.org/10.1016/j.seppur.2018.01.057

884 [38]Lin H.J, Peng W, Zhang MJ, Chen JR, Hong HC, Zhang Y. A review on anaerobic 885 membrane bioreactors:Applications, membrane fouling and future perspectives. 886 Desalination 2013;314:169-188. https://doi.org/10.1016/j.desal.2013.01.019

887 [39]Chang IS, Le-Clech P, Jefferson B, Judd S. Membrane fouling in membrane biore888 actors for wastewater treatment. J. Membr. Sci. 2002;128:1018-1029. 889 https://doi.org/10.1061/(ASCE)0733-9372(2002)128:11(1018).

890 [40]Cicek N. A review of membrane bioreactors and their potential application in the 891 treatment of agricultural wastewater. Can. Biosyst. Eng. 2003;45:6-37.

892 [41]Jalilnejad E, Sadeghpour P, Ghasemzadeh K. Chapter 7 - Achievements in 893 membrane bioreactors for wastewater and water treatment. In:Basile A, 894 Chasemzadeh K, Jalilnejad E, eds. Current Trends and Future Developments on 895 (Bio-) Membranes. Elsevier; 2020. p. 187-220. 
897 [42]Lin HJ, Xie K, Mahendran B, et al. Sludge properties and their effects on membrane 898 fouling in submerged anaerobic membrane bioreactors (SAnMBRs). Water Res. $899 \quad$ 2009;43:3827-3837. https://doi.org/10.1016/j.watres.2009.05.025

900 [43] Kim J, Lee CH, Choo KH. Control of struvite precipitation by selective removal of $901 \mathrm{NH}_{4}{ }^{+}$with dialyzer/zeolite in an anaerobic membrane bioreactor. Appl. Microbiol. 902 Biotechnol. 2007;75:187-193. https://doi.org/10.1007/s00253-006-0791-x.

903 [44]Kocadagistan E, Topcub N. Treatment investigation of the Erzurum City munic-ipal 904 wastewaters with anaerobic membrane bioreactors. Desalination 2007;216:367-376. 905 https://doi.org/10.1016/j.desal.2006.10.038.

906 [45]Lin H, Chen J, Wang F, Ding L, Hong H. Feasibility evaluation of submerged 907 anaerobic membrane bioreactor for municipal secondary wastewater treatment. 908 Desalination 2011;280:120-126. https://doi.org/10.1016/j.desal.2011.06.058

909 [46]Kanai M, Ferre V, Wakahara S, Yamamoto T, Moro M. A novel combination of 910 methane fermentation and MBR-Kubota Submerged Anaerobic Membrane 911 Bioreactor process. Desalination 2010;250:964-967.

912 https://doi.org/10.1016/j.desal.2009.09.082

913 [47]Alighardashi A, Pakan M, Jamshidi S, Shariati FP. Performance evaluation of 914 mem-brane bioreactor (MBR) coupled with activated carbon on tannery 915 wastewater treatment. Membr. Water. Treat. 2017;8:517-528. https://doi.org/10.12989/mwt.2017.8.6.517. 
917 [48]Iorhemen OT, Hamza RA, Tay JH. Membrane bioreactor (MBR) technology for 918 waste-water treatment and reclamation:membrane fouling. Membranes (Basel). 919 2016;6(2):33. https://doi.org/10.3390/membranes6020033.

920 [49]Ren J, McCutcheon JR. A new commercial biomimetic hollow fiber membrane for 921 forward osmosis. Desalination 2018;442:44-50. 922 https://doi.org/10.1016/j.desal.2018.04.015

923 [50]Harada H, Momonoi K, Yamazaki S, Takizawa S. Application of anaerobic-UF 924 membrane reactor for treatment of a waste-water containing high-strength 925 particulate organics. Water Sci. Technol. 1994;30:307-319.

926 [51]Herrera-Robledo M, Morgan-Sagastume JM, Noyola A. Biofouling and pollutant 927 removal during long-term operation of an anaerobic membrane bioreactor treating 928 municipal $\quad$ wastewater. 2010;26:23-30. 929 https://doi.org/10.1080/08927010903243923.

930 [52]Anjum F, Khan IM, Kim J, et al. Trends and progress in AnMBR for domestic 931 wastewater treatment and their impacts on process efficiency and membrane fouling. 932 Environ. Technol. Innov. 2021;21:101204. https://doi.org/10.1016/j.eti.2020.101204. 933 [53]Lettinga G, Rebac S, Zeeman G. Challenge of psychrophilic anaerobic wastewater 934 treatment. Trends Biotechnol. 2001;19:363-370. https://doi.org/10.1016/S0167$935 \quad 7799(01) 01701-2$

936 [54]Ho J, Sung S. Methanogenic activities in anaerobic membrane bioreactors (AnMBR) 937 treating synthetic municipal wastewater. Bioresour. Technol. 2010;101:2191-2196. https://doi.org/10.1016/j.biortech.2009.11.042 
939 [55]Watanabe R, Nie Y, Wakahara S, Komori D, Li YY. Investigation on the response 940 of anaerobic membrane bioreactor to temperature decrease from $25^{\circ} \mathrm{C}$ to $10^{\circ} \mathrm{C}$ in $941 \quad$ sewage treatment. Bioresour. Technol. 2017;243:747-754

942 https://doi.org/10.1016/j.biortech.2017.07.001

943 [56]Robles A, Ruano MV, Ribes J, Ferrer J. Performance of industrial scale hollow944 fibre membranes in a submerged anaerobic MBR (HF-SAnMBR) system at 945 mesophilic and psychrophilic conditions. Sep. Purif. Technol. 2013;104:290-296.

946 https://doi.org/10.1016/j.seppur.2012.12.004

947 [57]Ji JY, Chen YJ, Hu YS, et al. One-year operation of a 20-L submerged anaerobic 948 membrane bioreactor for real domestic wastewater treatment at room 949 temperature:Pursuing the optimal HRT and sustainable flux. Sci. Total Environ. $950 \quad 2021 ; 775$.

951 https://doi.org/10.1016/j.scitotenv.2021.145799

952 [58]Liu JW, Kang XY, Luan XR, Gao LT, Tian HY, Liu XL. Performance and 953 membrane fouling behaviors analysis with SVR-LibSVM model in a submerged 954 anaerobic membrane bioreactor treating low-strength domestic sewage. Environ. 955 Technol. Innov. 2020;19:100844. https://doi.org/10.1016/j.eti.2020.100844

956 [59]Lei Z, Ma Y, Wang J, Wang X.C.C, Li Q, Chen R. Biochar addition supports high 957 digestion performance and low membrane fouling rate in an anaerobic membrane 958 bioreactor under low temperatures. Bioresour. Technol. 2021;330:124966. 
960 [60]Kong Z, Wu J, Rong C, et al. Large pilot-scale submerged anaerobic membrane 961 bioreactor for the treatment of municipal wastewater and biogas production at $25^{\circ} \mathrm{C}$.

962 Bioresour. Technol. 2021;319:124123.

963 https://doi.org/10.1016/j.biortech.2020.124123

964 [61]Evans PJ, Parameswaran P, Lim K, et al. A comparative pilot-scale evaluation of 965 gas-sparged and granular activated carbon-fluidized anaerobic membrane 966 bioreactors for domestic wastewater Treatment. Bioresour. Technol. 2019;288. 967 https://doi.org/10.1016/j.biortech.2019.01.072

968 [62]Mei XJ, Wang ZW, Miao Y, Wu ZC. A pilot-scale anaerobic membrane bioreactor 969 under short hydraulic retention time for municipal wastewater 970 treatment:performance and microbial community identification. J. Water Reuse 971 Desalin. 2018;8:58-67. https://doi.org/10.2166/wrd.2017.164

972 [63]Chen C, Guo WS, Ngo $\mathrm{HH}$, et al. Impact of reactor configurations on the 973 performance of a granular anaerobic membrane bioreactor for municipal wastewater 974 treatment. Int. Biodeterior. Biodegrad. 2017;121:131-138. 975 http://dx.doi.org/10.1016/j.ibiod.2017.03.021

976 [64]Smith A.L, Skerlos S.J, Raskin L. Anaerobic membrane bioreactor treatment of 977 domestic wastewater at psychrophilic temperatures ranging from $15^{\circ} \mathrm{C}$ to $3^{\circ} \mathrm{C}$. 978 Environ. Sci. Water Res. Technol. 2014;1(1):56-64.

979 [65]Dong Q, Parker W, Dagnew M. Long term performance of membranes in an 980 anaerobic membrane bioreactor treating municipal wastewater. Chemosphere 2016;144:249-256. http://dx.doi.org/10.1016/j.chemosphere.2015.08.077 
982 [66]Seib MD, Berg KJ, Zitomer DH. Influent waste water microbiota and temperature 983 influence anaerobic Membrane bioreactor microbial community. Bioresour. 984 Technol. 2016;216:446-452. http://dx.doi.org/10.1016/j.biortech.2016.05.098

985 [67]Chen R, Nie YL, Hu YS, et al. Fouling behaviour of soluble microbial products and 986 extracellular polymeric ubstances in a submerged anaerobic membrane bioreactor 987 treating low-strength wastewater at room temperature. J. Membr. Sci. 2017;531:1-9. 988 http://dx.doi.org/10.1016/j.memsci.2017.02.046

989 [68]Yoo RH, Kim JH, McCarty PL, Bae JH. Effect of temperature on the treatment of 990 domestic wastewater with a staged anaerobic fluidized membrane bioreactor. Water 991 Sci. Technol. 2014;69:1145-1150. http://dx.doi.org/10.2166/wst.2013.793

992 [69]Shin C, McCarty PL, Kim J, Bae J. Pilot-scale temperate-climate treatment of 993 domestic wastewater with a staged anaerobicfluidized membrane bioreactor (SAF994 MBR). Bioresour. Technol. 2014;159:95-103. 995 http://dx.doi.org/10.1016/j.biortech.2014.02.060

996 [70]Garcia I.M, Mokosch M, Soares A, Pidouo M, Jefferson B. Impact on reactor 997 configuration on the performance of anaerobic MBRs:treatment of settled sewage in 998 temperate climates. Water Res. 2013;47:4853-4860. 999 https://doi.org/10.1016/j.watres.2013.05.008

1000 [71]Peña M, Nascimento TD, Gouveia J, et al. Anaerobic submerged membrane 1001 bioreactor (AnSMBR) treating municipal wastewater at ambient 1002 temperature:Operation and potential use for agricultural irrigation. Bioresour. Technol. 2019;282:285-293. https://doi.org/10.1016/j.biortech.2019.03.019 
1004 [72]Dong Q, Parker W, Dagnew M. Impact of $\mathrm{FeCl}_{3}$ do sing on AnMBR treatment of 1005 municipal wastewater. Water 2015;80:281-293. 1006 http://dx.doi.org/10.1016/j.watres.2015.04.025

1007 [73]Nie Y, Kato H, Sugo T, Hojo T, Tian X, Li Y.Y. Effect of anionic surfactant 1008 inhibition on sewage treatment by a submerged anaerobic membrane bioreactor. 1009 Efficiency, sludge activity and methane recovery. Chem. Eng. J. 2017b;315:83-91. 1010 https://doi.org/10.1016/j.cej.2017.01.022

1011 [74]Chen R, Nie Y, Ji J, et al. Submerged anaerobic membrane bioreactor (SAnMBR) 1012 performance on sewage treatment. Removal efficiencies, biogas production and 1013 membrane fouling. Water Sci. Technol. 2017c;76:1308-1317. $1014 \quad$ https://doi.org/10.2166/wst.2017.240.

1015 [75]Chen R, Nie Y, Kato H, e. Methanogenic degradation of toilet-paper cellulose upon 1016 sewage treatment in an anaerobic membrane bioreactor at room temperature. 1017 Bioresour. Technol. 2017d;228:69-76. $\quad$ https://doi$1018 \quad$ org.aure.unab.edu.co/10.1016/j.biortech.2016.12.089

1019 [76]Gouveia J, Plaza F, Garralon G, Fdz-Polanco F, Peña M. Long-term operation of a 1020 pilot scale anaerobic membrane bioreactor (AnMBR) for the treatment of municipal 1021 wastewater under psychrophilic conditions. Bioresour. Technol. 2015b;185:2251022 233. https://doi.org/10.1016/j.biortech.2015.03.002.

1023 [77]Yue X, Koh YKK, Ng HY. Effects of dissolved organic matters (DOMs) on 1024 membrane fouling in anaerobic ceramic membrane bioreactors (AnCMBRs) 
1025 treating domestic wastewater. Water Res. 2015;86:96-107. 1026 https://doi.org/10.1016/j.watres.2015.07.038.

1027 [78]Dolejs P, Ozcan O, Bair R, et al. Effect of psychrophilic temperature shocks on a 1028 gas-lift anaerobic membrane bioreactor (Gl-AnMBR) treating synthetic domestic 1029 wastewater. J. Water Process Eng. 2017;16:108-114. 1030 https://doi.org/10.1016/j.jwpe.2016.12.005.

1031 [79]Gouveia J, Plaza F, Garralon G, Fdz-Polanco F, Peña M. A novel configuration for 1032 an anaerobic submerged membrane bioreactor (AnSMBR). Long-term treatment of 1033 municipal wastewater under psychrophilic conditions. Bioresour. Technol. $1034 \quad$ 2015a;198:510-519. https://doi.org/10.1016/j.biortech.2015.09.039

1035 [80]Brown N. Methane dissolved in wastewater exiting UASB reactors:concentration 1036 measurement and methods for neutralization. Department of Energy Technology, 1037 Royal Institute of Technology (KTH). Stockholm; 2006. p. 174.

1038 [81]Chen Y, Cheng JJ, Creamer KS. Inhibition of anaerobic digestion process:a review. 1039 Bioresour. Technol. 2008;99:4044-4064. 1040 https://doi.org/10.1016/j.biortech.2007.01.057

1041 [82]Yeo H, An J, Reid R, Rittmann BE, Lee HS. Contribution of liquid/gas mass1042 transfer limitations to dissolved methane oversaturation in anaerobic treatment of 1043 dilute wastewater. Environ. Sci. Technol. 2015;17:10366-10372. $1044 \quad$ https://doi.org/10.1021/acs.est.5b02560. 
1045 [83]Song XY, Luo WH, Hai FI, et al. Resource recovery from wastewater by anaerobic 1046 membrane bioreactors:Opportunities and challenges. Bioresour. Technol. $1047 \quad$ 2018;270:669-677. https://doi.org/10.1016/j.biortech.2018.09.001.

1048 [84]Mai DT, Kunacheva C, Stuckey DC. A review of posttreatment technologies for 1049 anaerobic effluents for discharge and recycling of wastewater. Crit. Rev. Environ. 1050 Sci.Technol. 2018;48:167-209. https://doi.org/10.1080/10643389.2018.1443667.

1051 [85]Crone BC, Garland JL, Sorial GA, Vane LM. Significance of dissolved methane in 1052 effluents of anaerobically treated low strength wastewater and potential for recovery 1053 as an energy product:A review. Water Res. 2016;104:520-531. 1054 https://doi.org/10.1016/j.watres.2016.08.019.

1055 [86]Velasco P, Jegatheesan V, Othman M. Recovery of dissolved methane from 1056 anaerobic membrane bioreactor using degassing membrane contactors. Front. 1057 Environ. Sci. 2018;6:1-6. https://doi.org/10.3389/fenvs.2018.00151.

1058 [87]Vinardell S, Astals S, Pecesv M, et al. Advances in anaerobic membrane bioreactor 1059 technology for municipal wastewater treatment:A 2020 updated review. Renew. 1060 Sust. Energy Rev. 2020;130:109936. https://doi.org/10.1016/j.rser.2020.109936 1061 [88]Cookney J, Cartmell E, Jefferson B, McAdam EJ. Recovery of methane from 1062 anaerobic process effluent using poly-di-methyl-siloxane membrane contactors. 1063 Water Sci. Technol. 2012;65:604-610. https://doi.org/10.2166/wst.2012.897.

1064 [89]Cookney J, McLeod A, Mathioudakis V, et al. Dissolved methane recovery from 1065 anaerobic effluents using hollowfibre membrane contactors. J. Membr. Sci. 2016;502:141-150. https://doi.org/10.1016/j.memsci.2015.12.037. 
1067 [90]Meng F, Chae SR, Drews A, Kraume M, Shin HS, Yang F. Recent advances in 1068 membrane bioreactors (MBRs):Membrane fouling and membrane material. Water 1069 Res. 2009;43:1489-1512. https://doi.org/10.1016/j.watres.2008.12.044.

1070 [91]Tu X, Zhang S, Xu L, Zhang M, Zhu J. Performance and fouling characteristics in a 1071 membrane sequence batch reactor (MSBR) system coupled with aerobic granular 1072 sludge. Desalination 2010;261:191-196.

1073 https://doi.org/10.1016/j.desal.2010.03.034.

1074 [92]Koros WJ, Ma YH, Shimidzu T. Terminology for membranes and membrane 1075 processes (IUPAC Recommendations 1996). Pure Appl. Chem.1996;68:1479-1489. 1076 https://doi.org/10.1016/0376-7388(96)82861-4.

1077 [93]Liao BQ, Kraemer JT, Bagley DM. Anaerobic membrane bioreactors:applications 1078 and research directions. Crit. Rev. Environ. Sci. Technol. 2006;36:489-530.

1079 [94]Guo W, Ngo H.H, Li J. A mini-review on membrane fouling. Bioresour. Technol. $1080 \quad$ 2012;122:27-34. https://doi.org/10.1016/j.biortech.2012.04.089.

1081 [95]Jiang T, Kennedy MD, Van Der Meer WGJ, Vanrolleghem PA, Schippers JC. The 1082 role of blocking and cake filtration in MBR fouling. Desalination 2003;157:3351083 343. https://doi.org/10.1016/S0011-9164(03)00414-4.

1084 [96]Wang XM, Waite TD. Role of Gelling Soluble and Colloidal Microbial Products in 1085 Membrane Fouling. Environ. Sci. Technol. 2009;43:9341-9347. 1086 https://doi.org/10.1021/es9013129. 
1087 [97]Wang Z, Wu Z. A Review of Membrane Fouling in MBRs:Characteristics and Role 1088 of Sludge Cake Formed on Membrane Surfaces. Separ. Purif. Technol. 1089 2009;44:3571-3596. https://doi.org/10.1080/01496390903182578.

1090 [98]Su X, Tian Y, Li H. New insights into membrane fouling based on characterization 1091 of cake sludge and bulk sludge:An especial attention to sludge aggregation. 1092 Bioresour. Technol. 2013;128:586-592.

1093 https://doi.org/10.1016/j.biortech.2012.11.005.

1094 [99]Le-Clech P, Chen V, Fane TAG. Fouling in membrane bioreactors used in 1095 wastewater treatment. J. Membr. Sci. 2006;284:17-53. 1096 https://doi.org/10.1016/j.memsci.2006.08.019

1097 [100]Drews A. Membrane fouling in membrane bioreactors-Characterisation, 1098 contradictions, cause and cures. J. Membr. Sci.2010;363:1-28. 1099 https://doi.org/10.1016/j.memsci.2010.06.046.

1100 [101]Ye Y, Clech PL, Chen V, Fane AG. Evolution of fouling during crossflow 1101 filtration of model EPS solutions. J. Membr. Sci. 2005;264:190-199. 1102 https://doi.org/10.1016/j.memsci.2005.04.040.

1103 [102]Ognier S, Wisniewski C, Grasmick A. Membrane bioreactor fouling in sub-critical 1104 filtration conditions:A local critical flux concept. J. Membr. Sci. 2004;229:171-177. 1105 https://doi.org/10.1016/j.memsci.2003.10.026.

1106 [103]Cho BD, Fane AG. Fouling transients in nominally sub-criticalflux operation of a 1107 membrane bioreactor. J. Membr. Sci. 2002;209:391-403. https://doi.org/10.1016/S0376-7388(02)00321-6. 
1109 [104]Hwang BK, Lee WN, Yeon KM, et al. Correlating TMP increases with microbial 1110 characteristics in the bio-cake on the membrane surface in a membrane bioreactor.

1111 Environ. Sci. Technol. 2008;42:3963-3968. https://doi.org/10.1021/es7029784.

1112 [105]Oh HS, Yeon KM, Yang CS. Control of membrane biofouling in MBR for

1113 wastewater treatment by quorum quenching bacteria encapsulated in microporous

1114 membrane. Environ. Sci. Technol. 2012;46:4877-4884.

$1115 \quad$ https://doi.org/10.1021/es204312u.

1116 [106]Vanysacker L, Declerck P, Bilad MR, Vankelecom IFJ. Biofouling on

1117 microfiltration membranes in MBRs: Role of membrane type and microbial

1118 community. $\quad$ J. Membr. $\quad$ Sci.

$1119 \quad$ https://doi.org/10.1016/j.memsci.2013.11.024.

1120 [107]Meng F, Zhang S, Oh Y, Zhou Z, Shin HS, Chae SR. Fouling in membrane

1121 bioreactors: an updated review. Water Res. 2017;114:151-180.

1122 https://doi.org/10.1016/j.watres.2017.02.006.

1123 [108]Herrera-Robledo M, Cid-León DM, Morgan-Sagastume JM, Noyola A. Biofouling

1124 in an anaerobic membrane bioreactor treating municipal sewage. Separ. Purif

1125 Technol. 2011;81:49-55. https://doi.org/10.1016/j.seppur.2011.06.041.

1126 [109]Lin H, Zhang M, Wang F, Meng F, Liao BQ, Hong H. A critical review of 1127 extracellular polymeric substances (EPSs) in membrane bioreactors: characteristics, 1128 roles in membrane fouling and control strategies. J. Membr. Sci. 2014;460:110-125. 1129 https://doi.org/10.1016/j.memsci.2014.02.034. 
1130 [110]Frølund B, Griebe T, Nielsen PH. Enzymatic activity in the activated-sludge floc 1131 matrix. Appl. Microbiol. Biotechnol. 1995;43:755-761. 1132 https://doi.org/10.1007/BF00164784.

1133 [111]Ruiz-Hernando M, Cabanillas E, Labanda J, Llorens J. Ultrasound, thermal and 1134 alkali treatments affect extracellular polymeric substances (EPSs) and improve 1135 waste activated sludge dewatering. Process Biochem. 2015;50:438-446.

1136 https://doi.org/10.1016/j.procbio.2015.01.001.

1137 [112]Benyahia B, Sari T, Cherki B, Harmand J. Anaerobic membrane bioreactor 1138 modeling in the presence of soluble microbial products (SMP) - the anaerobic 1139 model $\mathrm{AM}_{2}$ b. Chem. Eng. J. 2013;228:1011-1022. 1140 https://doi.org/10.1016/j.cej.2013.05.073.

1141 [113]Mutamim NSA, Noor ZZ, Hassan MAA, Yuniarto A, Olsson G. Membrane 1142 bioreactor: Applications and limitations in treating high strength industrial 1143 wastewater. Chem. Eng. J. 2013;225:109-119. 1144 https://doi.org/10.1016/j.cej.2013.02.131.

1145 [114]Mo Y, Xiao K, Shen Y. A new perspective on the effect of complexation between 1146 calcium and alginate on fouling during nanofiltration. Sep. Purif. Technol. $1147 \quad$ 2011;82:121-127. https://doi.org/10.1016/j.seppur.2011.08.033.

1148 [115]Wang Z, Ma J, Tang CY, Kimura K, Wang Q, Han X. Membrane cleaning in 1149 membrane bioreactors: A review. J. Membr. Sci. 2014;468:276-307. 1150 https://doi.org/10.1016/j.memsci.2014.05.060. 
1151 [116]Wang Z, Wu Z, Yin X, Tian L. Membrane fouling in a submerged membrane 1152 bioreactor (MBR) under sub-critical flux operation: Membrane foulant and gel layer 1153 characterization. J. Membr. Sci. 2008;325:238-244. 1154 https://doi.org/10.1016/j.memsci.2008.07.035.

1155 [117]Arabi S, Nakhla G. Impact of calcium on the membrane fouling in membrane 1156 bioreactors. $\quad$ J. Membr. $\quad$ Sci. $2008 ; 314: 134-142$. 1157 https://doi.org/10.1016/j.memsci.2008.01.037.

1158 [118]Bottino A, Capannelli G, Comite A, Mangano R. Critical flux in submerged 1159 membrane bioreactors for municipal wastewater treatment. Desalination $1160 \quad$ 2009;245:748-753. https://doi.org/10.1016/j.desal.2009.02.047.

1161 [119]Wu J, Huang X. Effect of mixed liquor properties on fouling propensity in 1162 membrane bioreactors. J. Membr. Sci. 2009;342:88-96. 1163 https://doi.org/10.1016/j.memsci.2009.06.024.

1164 [120]Deng L, Guo W, Ngo HH, et al. Biofouling and control approaches in membrane 1165 bioreactors. Bioresour. Technol. 2016;221:656-665. 1166 https://doi.org/10.1016/j.biortech.2016.09.105.

1167 [121]Guglielmi G, Andreottola G. Selection and Design of Membrane Bioreactors in 1168 Environmental Bioengineering. In: Wang L, Ivanov V, Tay JH, eds. Environmental 1169 Biotechnology. Handbook of Environmental Engineering, vol 10. Totowa: Humana 1170 Press; 2010. p. 439-514. https://doi.org/10.1007/978-1-60327-140-0_10. 
1171 [122]Ma Z, Wen X, Zhao F, et al. Effect of temperature variation on membrane fouling 1172 and microbial community structure in membrane bioreactor. Bioresour. Technol. 1173 2013;133:462-468. https://doi.org/10.1016/j.biortech.2013.01.023

1174 [123]Chen R, Nie YL, Hu YS. Fouling behaviour of soluble microbial products and 1175 extracellular polymeric substances in a submerged anaerobic membrane bioreactor 1176 treating low-strength wastewater at room temperature. $\quad J . \quad$ Membr. Sci. $1177 \quad$ 2017;531:1-9. https://doi.org/10.1016/j.memsci.2017.02.046.

1178 [124]Huang Z, Ong SL, Ng HY. Submerged anaerobic membrane bioreactor for low1179 strength wastewater treatment: Effect of HRT and SRT on treatment performance 1180 and membrane fouling. Water Res. 2011;45:705-713. 1181 https://doi.org/10.1016/j.watres.2010.08.035.

1182 [125]Kochkodan V, Hilal N. A comprehensive review on surface modified polymer 1183 membranes for biofouling mitigation. Desalination 2015;356:187-207. 1184 https://doi.org/10.1016/j.desal.2014.09.015.

1185 [126]Jeison D, Telkamp P, Vanlier JB. Thermophilic sidestream anaerobic membrane 1186 bioreactors: The shear rate dilemma. Water Environ. Res. 2009;81:2372-2380. 1187 https://doi.org/10.2175/106143009X426040.

1188 [127]Ozgun H, Dereli RK, Ersahin ME, Kinaci C, Spanjers H, Van Lier JB. A review of 1189 anaerobic membrane bioreactors for municipal wastewater treatment: integration 1190 options, limitations and expectations. Sep. Purif. Technol. 2013;118: 9-104. 1191 https://doi.org/10.1016/j.seppur.2013.06.036. 
1192 [128]Gede Wenten I, Friatnasary DL, Khoiruddin K, Setiadi T, Boopathy R. Extractive 1193 membrane bioreactor (EMBR): recent advances and applications. Bioresour. 1194 Technol. 2020;297: 122424. https://doi.org/10.1016/j.biortech.2019.122424

1195 [129]Ahmad R, Aslam M, Park E, Chang S, Kwon D, Kim J. Submerged low-cost 1196 pyrophyllite ceramic membrane filtration combined with GAC as fluidized particles 1197 for industrial wastewater treatment. Chemosphere 2018;206:784-792. 1198 https://doi.org/10.1016/j.chemosphere.2018.05.045.

1199 [130]Aslam M, Kim J. Investigating membrane fouling associated with GAC fluidi1200 zation on membrane with effluent from anaerobic fluidized bed bioreactor in do1201 mestic wastewater treatment. Environ. Sci. Pollut. Res. Int. 2019;26: 1170-1180.

1202 [131] Shoener BD, Zhong C, Greiner AD, Khunjar WO, Hong PY, Guest JS. Design of 1203 anaerobic membrane bioreactors for the valorization of dilute organic carbon waste $1204 \quad$ streams. Energy Environ. Sci. 2016;9:1102.

1205 [132]Charfi A, Aslam M, Kim J. Modelling approach to better control biofouling in 1206 fluidized bed membrane bioreactor for wastewater treatment. Chemosphere. 1207 2018a;191:136-144. https://doi.org/10.1016/j.chemosphere.2017.09.135.

1208 [133]Zhang Q, Singh S, Stuckey D.C. Fouling reduction using adsorbents/flocculants in 1209 a submerged anaerobic membrane bioreactor. Bioresour. Technol. 2017;239:226$1210 \quad$ 235. https://doi.org/10.1016/j.biortech.2017.05.022.

1211 [134]McCarty PL, Kim J, Shin C, Lee PH, Bae J. Anaerobic fluidized bed membrane 1212 bioreactors for the treatment of domestic wastewater. In: Anaerobic biotechnology: 1213 Environmental protection and resource recovery. World Scientific. 2015. 
1214 [135]Belfort G, Pimbley JM, Greiner A, Chung KY. Diagnosis of membrane fouling 1215 using a rotating annular filter. 1. Cell culture media. J. Membr. Sci. 1993;77:1-22.

1216 https://doi.org/10.1016/0376-7388(93)85231-K.

1217 [136]Ruigómez I, González E, Guerra S, Rodríguez-Gómez LE, Vera L. Evaluation of a 1218 novel physical cleaning strategy based on HF membrane rotation during the 1219 backwashing/relaxation phases for anaerobic submerged MBR. J. Membr. Sci. $1220 \quad$ 2017;526:181-190. https://doi.org/10.1016/j.memsci.2016.12.042.

1221 [137]Yoo SS, Chu KH, Choi IH, Mang JS, Ko KB. Operating cost reduction of UF 1222 membrane filtration process for drinking water treatment attributed to chemical 1223 cleaning optimization. J. Environ. Manag. 2018;206:1126-1134.

1224 https://doi.org/10.1016/j.jenvman.2017.02.072.

1225 [138]Malaeb L, Le-Clech P, Vrouwenvelder JS, Ayoub GM, Saikaly PE. Do biological1226 based strategies hold promise to biofouling control in MBRs? Water Res. $1227 \quad$ 2013b;47:5447-5463. https://doi.org/10.1016/j.watres.2013.06.033.

1228 [139]Bagheri M, Mirbagheri SA. Critical review of fouling mitigation strategies in 1229 membrane bioreactors treating water and wastewater. Bioresour. Technol. $1230 \quad 2018 ; 258: 318-334$. https://doi.org/10.1016/j.biortech.2018.03.026.

1231 [140]Aslam M, Yang P, Lee PH, Kim J. Novel staged anaerobic fluidized bed ceramic 1232 membrane bioreactor: energy reduction, fouling control and microbial 1233 characterization. J. Membr. Sci. 2018b;553:200-208. 1234 https://doi.org/10.1016/j.memsci.2018.02.038. 
1235 [141]Levitsky I, Duek A, Arkhangelsky E. Understanding the oxidative cleaning of UF membranes. $J$.

Membr.

Sci.

2011;377:206-213.

1237 https://doi.org/10.1016/j.memsci.2011.04.046.

1238 [142]Jhaveri JH, Murthy Z. A comprehensive review on anti-fouling nanocomposite 1239 membranes for pressure driven membrane separation processes. Desalination 1240 2016;379:137-154. https://doi.org/10.1016/j.desal.2015.11.009.

1241 [143]Hegab HM, Wimalasiri Y, Ginic-Markovic M. Improving the fouling resistance of 1242 brackish water membranes via surface modification with graphene oxide 1243 functionalized chitosan. Desalination 2015;365:99-107. 1244 https://doi.org/10.1016/j.desal.2015.02.029.

1245 [144]Ariono D, Wardani AK. Modification and applications of hydrophilic 1246 polypropylene membrane. IOP Conf. Ser. Mater. Sci. Eng. 2017;214:012014. 1247 https://doi.org/10.1088/1757-899X/214/1/012014.

1248 [145]Yu HY, Hu MX, Xu ZK. Surface modification of polypropylene microporous 1249 membranes to improve their antifouling property in MBR: $\mathrm{NH}_{3}$ plasma treatment. 1250 Sep. Purif. Technol. 2005;45:8-15. https://doi.org/10.1016/j.seppur.2005.01.012. 1251 [146]Yu HY, Xie Y, Hu MX. Surface modification of polypropylene microporous 1252 membrane to improve its antifouling property in $\mathrm{MBR}$ : $\mathrm{CO}_{2}$ plasma treatment. J. 1253 Membr. Sci. 2005;254: 219-227. https://doi.org/10.1016/j.memsci.2005.01.010. 1254 [147]Wang LL, Wu JJ, Zhang ZB. Methoxy polyethylene glycol grafting on 1255 polypropylene membrane for enhanced antifouling characteristics - Effect of 1256 pendant length and grafting density. Sep. Purif. Technol. 2016;164:81-88. 
1257 [148]Pi JK, Yang HC, Wan LS. Polypropylene microfiltration membranes modified 1258 with $\mathrm{TiO}_{2}$ nanoparticles for surface wettability and antifouling property. J. Membr. 1259 Sci. 2016;500:8-15. https://doi.org/10.1016/j.memsci.2015.11.014.

1260 [149]Santhosh C, Velmurugan V, Jacob G. Role of nanomaterials in water treatment 1261 applications: A review. Chem. Eng. J. 2016;306:1116-1137. 1262 https://doi.org/10.1016/j.cej.2016.08.053.

1263 [150]Pollice A, Brookes A, Jefferson B, Judd S. Sub-critical flux fouling in membrane 1264 bioreactors - a review of recent literature. Desalination 2005;174:221-230.

1265 https://doi.org/10.1016/j.desal.2004.09.012.

1266 [151]Salazar-Peláez M.L, Morgan-Sagastume J.M, Noyola A. Influence of hydraulic 1267 retention time on fouling in a UASB coupled with an external ultrafiltration 1268 membrane treating synthetic municipal wastewater. Desalination 2011;277:1641269 170. https://doi.org/10.1016/j.desal.2011.04.021.

1270 [152]Park H, Choo KH, Lee CH. Flux enhancement with powdered activated carbon 1271 addition in the membrane anaerobic bioreactor. Sep. Sci. Technol. 1999;34:27811272 2792. https://doi.org/10.1081/SS-100100804.

1273 [153]Skouteris G, Saroj D, Melidis P. The effect of activated carbon addition on 1274 membrane bioreactor processes for wastewater treatment and reclamation - a critical 1275 review. Bioresour. Technol. 2015;185:399-410. 1276 https://doi.org/10.1016/j.biortech.2015.03.010. 
1277 [154]Akram A, Stuckey D.C. Flux and performance improvement in a submerged an1278 aerobic membrane bioreactor (SAMBR) using powdered activated carbon (PAC). 1279 Process Biochem. 2008;43:93-102. https://doi.org/10.1016/j.procbio.2007.10.020.

1280 [155]Ying Z, Ping G. Effect of powdered activated carbon dosage on retarding mem1281 brane fouling in MBR. Sep. Purif. Technol. 2006;52:154-160. $1282 \quad$ https://doi.org/10.1016/j.seppur.2006.04.010

1283 [156]Damayanti A, Ujang Z, Salim MR. The influenced of PAC, zeolite, and 1284 Moringaoleifera as biofouling reducer (BFR) on hybrid membrane bioreactor of 1285 palm oil mill effluent (POME). Bioresour. Technol. 2011;102:4341-4346. $1286 \quad$ https://doi.org/10.1016/j.biortech.2010.12.061

1287 [157]Song KG, Kim Y, Ahn KH. Effect of coagulant addition on membrane fouling and 1288 nutrient removal in a submerged membrane bioreactor. Desalination 2008;221:4671289 474. https://doi.org/10.1016/j.desal.2007.01.107.

1290 [158]Ding A, Fan Q, Cheng R, Sun G, Zhang M, Wu D. Impacts of applied voltag on 1291 microbial electrolysis cell-anaerobic membrane bioreactor (MEC-AnMBR) and its 1292 membrane fouling mitigation mechanism. Chem. Eng. J. 2018;333:630-635. 1293 https://doi.org/10.1016/j.cej.2017.09.190

1294 [159]Liu Y, Zhang Y, Quan X. Effects of an electric field and zero valent iron on 1295 anaerobic treatment of azo dye wastewater and microbial community structures.
1296
Bioresour.
Technol.
2011;102:2578-2584.

1297 https://doi.org/10.1016/j.biortech.2010.11.109. 
1298 [160]Yang Y, Qiao S, Jin R, Zhou J, Quan X. Novel anaerobic electrochemical 1299 membrane bioreactor with a CNTs hollow fiber membrane cathode to mitigate membrane fouling and enhance energy recovery. Environ. Sci. Technol. 2019;53:

$1301 \quad$ 1014-1021. https://doi.org/10.1021/acs.est.8b05186

1302 [161]Katuri KP, Bettahalli NMS, Wang XB. A microfiltration polymer-based hollow1303 fiber cathode as a promising advanced material for simultaneous recovery of energy 1304 and $\quad$ water. $A d v . \quad$ Mater. 2016;28:9504-9511. $1305 \quad$ https://doi.org/10.1002/adma.201603074

1306 [162]Alepu OE, Segun GA, Ikhumhen HO. Formation mechanism and performance 1307 of dynamic membrane technology for municipal wastewater treatment - A review. $1308 \quad$ Waste Manage. 2016;1:3-8. https://doi.org/10.4172/2475-7675.1000113.

1309 [163]Marcinkowsky AE, Kraus KA, Phillips HO. Hyperfiltration Studies.IV.Salt 1310 Rejection by Dynamically Formed Hydrous Oxide Membranes. J. Am. Chem. Soc. 1966;88:5744-5746. https://doi.org/10.1021/ja00976a013

1312 [164]Fan B, Huang X. Characteristics of a self-forming dynamic membrane coupled 1313 with a bioreactor for municipal wastewater. Environ. Sci. Technol. 2002;36:52451314 5251. https://doi.org/10.1021/es025789n

1315 [165]Davila M, Kassab G, Klapwijk A, Lier, et al. Anaerobic membrane bioreactors: 1316 Are membranes really? Electron. J. Biotechnol. 2008;11:1-7. 1317 http://dx.doi.org/10.4067/S0717-34582008000400001.

1318 [166]Na L, Yi H, Lu YZ, Zeng RJ. In-situ biogas sparging enhances the performance of 1319 an anaerobic membrane bioreactor(AnMBR) with mesh filter in low-strength 
wastewater treatment. Appl. Microbiol. Biotechnol. 2016;100:6081-6089. https://doi.org/10.1007/s00253-016-7455-2.

1322 [167]Alibardi L, Bernava N, Cossu R, Spagni A. Anaerobic dynamic membrane 1323 bioreactor for wastewater treatment at ambient temperature. Chem. Eng. J. 1324 2016;284:130-138. https://doi.org/10.1016/j.cej.2015.08.111.

1325 [168]Ersahin ME, Tao Y, Ozgun H, Gimenez JB, Spanjers H, Van Lier JB. Impact of 1326 anaerobic dynamic membrane bioreactor configuration on treatment and filterability 1327 performance. $\quad$ J. Membr. Sci. 2017;526:387-394. 1328 https://doi.org/10.1016/j.memsci.2016.12.057.

1329 [169]Holloway RW, Childress AE, Dennett KE. Forward osmosis for concentration of 1330 anaerobic digester centrate. Water Res. 2007;41:4005-4014. 1331 https://doi.org/10.1016/j.watres.2007.05.054.

1332 [170]Chen $\mathrm{C}$, Guo W, Ngo $\mathrm{HH}$, et al. Challenges in biogas production from anaerobic 1333 membrane bioreactors. Renew. Energy. 2016;98: 120-134. 1334 https://doi.org/10.1016/j.renene.2016.03.095.

1335 [171]Chen L, Gu Y, Cao C, Zhang J, Ng JW, Tang C. Performance of a submerged 1336 anaerobic membrane bioreactor with forward osmosis membrane for low-strength 1337 wastewater treatment. Water Res. 2014;50:114-123. 1338 https://doi.org/10.1016/j.watres.2013.12.009

1339 [172]Gao Y, Fang Z, Chen C, Zhu X, Liang P, Qiu Y. Evaluating the performance of 1340 inorganic draw solution concentrations in an anaerobic forward osmosis membrane 
1341 bioreactor for real municipal sewage treatment. Bioresour. Technol. $1342 \quad$ 2020;307:123254. https://doi.org/10.1016/j.biortech.2020.123254.

1343 [173]Nguyen NC, Nguyen HT, Chen SS, et al. A novel osmosis membrane bioreactor1344 membrane distillation hy-brid system for wastewater treatment and reuse. Bioresour. 1345 Technol. 2016;209:8-15. https://doi.org/10.1016/j.biortech.2016.02.102

1346 [174]Wijekoon KC, Hai FI, Kang J, Price WE, Cath TY, Nghiem LD. Rejection and 1347 fate of trace organic compounds (TrOCs) during membrane distillation. J. Membr. $1348 \quad$ Sci. 2014a;453:636-642. https://doi.org/10.1016/j.memsci.2013.12.002.

1349 [175]Song XY, Luo WH, McDonald J, et al. An anaerobic membrane bioreactor 1350 membrane distillation hybrid system for energy recovery and water reuse: Removal 1351 performance of organic carbon, nutrients, and trace organic contaminants. Sci. Total 1352 Environ. 2018;628:358-365. https://doi.org/10.1016/j.scitotenv.2018.02.057.

1353 [176]Kim HC, Shin J, Won S, Lee JY, Maeng SK, Song KG. Membrane distillation 1354 combined with an anaerobic moving bed biofilm reactor for treating municipal 1355 wastewater. Water Res. 2015a;71:97-106. 1356 https://doi.org/10.1016/j.watres.2014.12.048.

1357 [177]Muhammad KS, Ayesha K, Prangya RR, et al A brief review of anaerobic 1358 membrane bioreactors emphasizing recent advancements, fouling issues and future 1359 perspectives. $\quad$ J. $\quad$ Environ. $\quad$ Manage. 2020;270: 110909. $1360 \quad$ https://doi.org/10.1016/j.jenvman.2020.110909. 


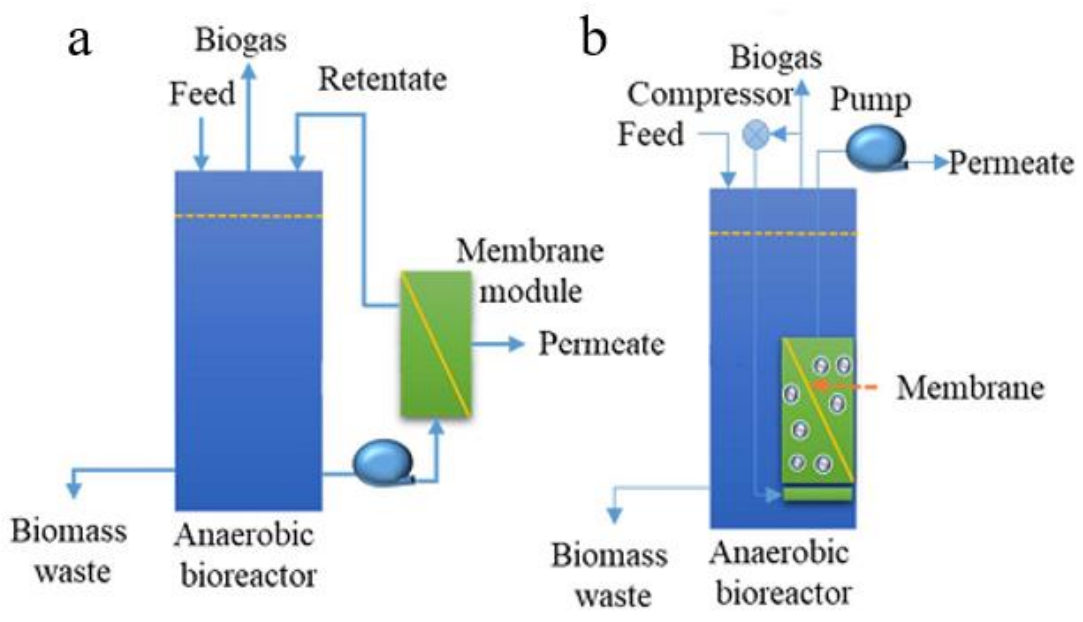

1363 Fig. 1. (a) Sidestream AnMBR and (b) submerged AnMBR [1].

1364

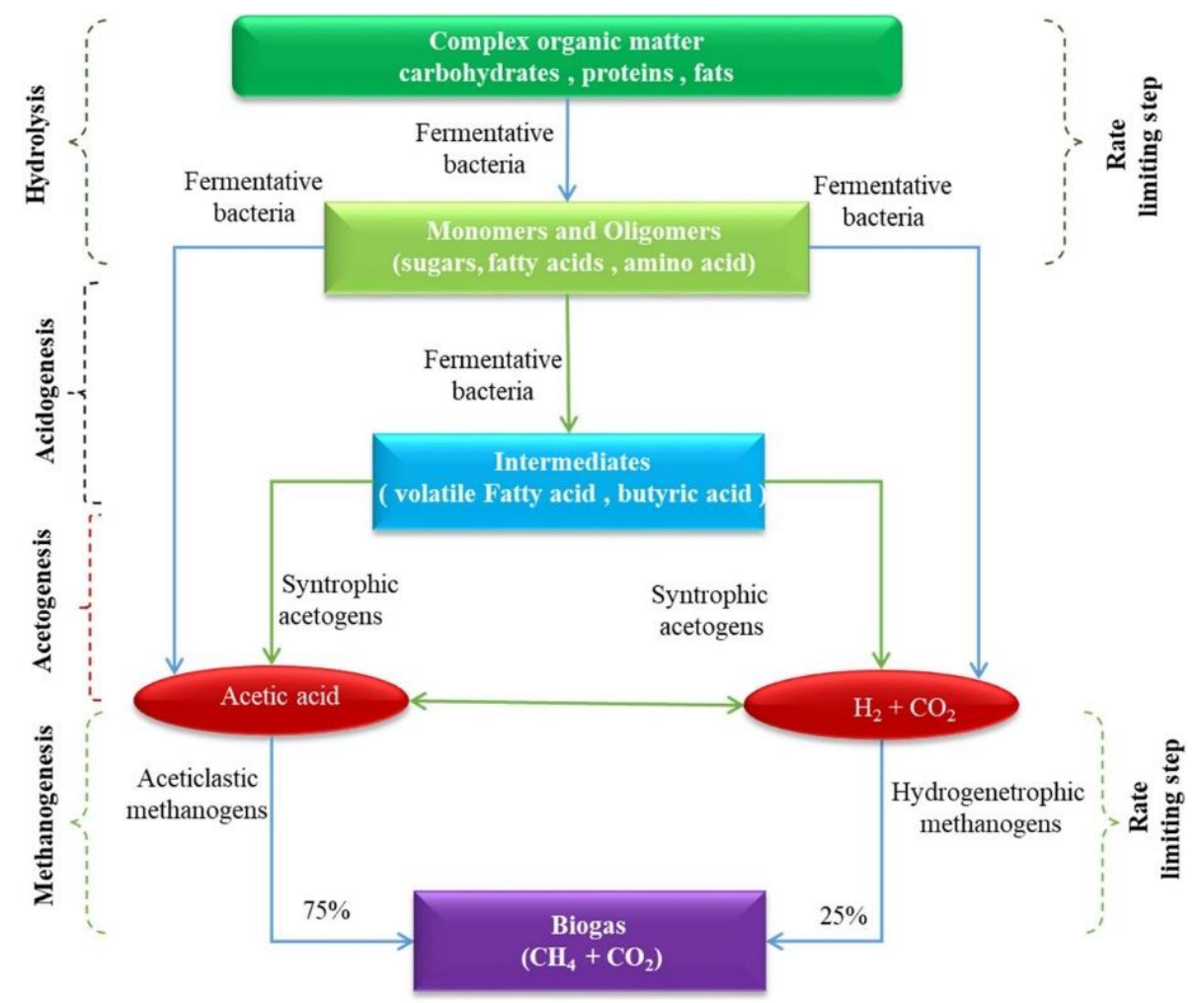

1366 Fig. 2. Anaerobic treatment in AnMBRs [1]. 


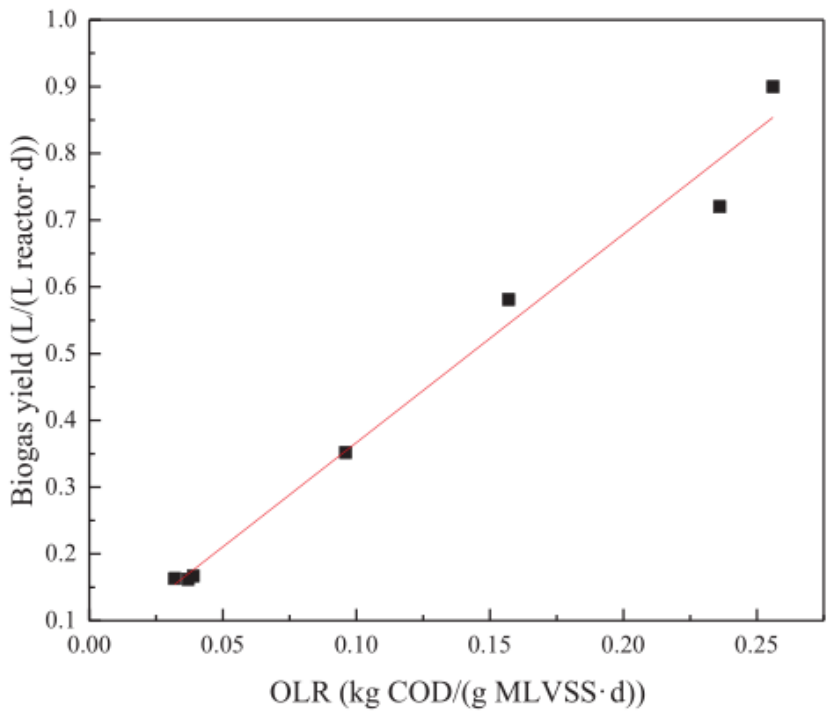

1367

1368 Fig. 3. Comparative analysis of OLR and biogas yield [23].

1369

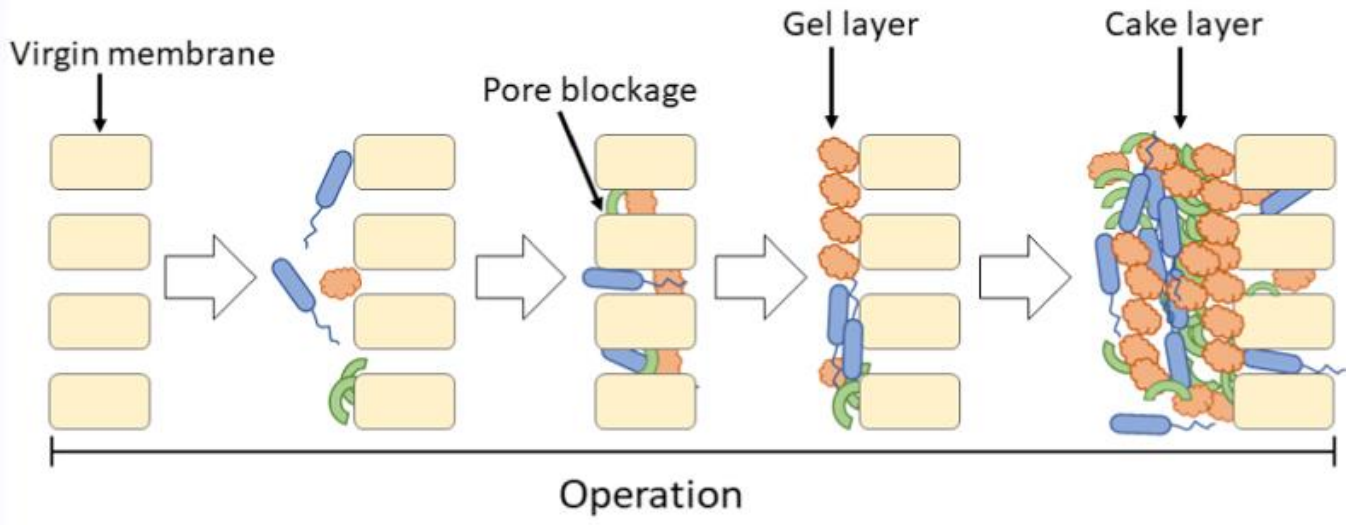

Colloids

Biological particles

Solute

1371 Fig. 4. Mechanisms of membrane fouling in AnMBRs [177]. 
Table 1. Characteristics of Different Membrane Materials [2]

\begin{tabular}{|c|c|c|c|c|c|}
\hline \multicolumn{2}{|c|}{ Membrane materials } & \multirow{2}{*}{$\begin{array}{c}\text { Pore } \\
\text { size }(\boldsymbol{\mu m}) \\
0.04 / 0.2 / \\
0.4 / 0.45 / \\
1.0\end{array}$} & \multirow{2}{*}{$\begin{array}{c}\text { Membrane } \\
\text { Flux }\left(\mathbf{L} / \mathbf{m}^{2} / \mathbf{h}\right) \\
<25\end{array}$} & \multirow{2}{*}{$\begin{array}{c}\begin{array}{c}\text { Membrane } \\
\text { treatment }\end{array} \\
\mathrm{MF} / \mathrm{UF}\end{array}$} & Advantages \\
\hline Polymeric & PVDF & & & & $\begin{array}{l}\text { High chemical tolerance to chlorine } \\
\text { and most oxidants; highly } \\
\text { commercialized, } \\
\text { price in the medium range }\end{array}$ \\
\hline & PTFE & $\begin{array}{l}0.1 / 0.22 / \\
0.45 / 0.8 / \\
1.0\end{array}$ & $<40$ & UF & $\begin{array}{l}\text { Excellent chemical tolerant to } \\
\text { chlorine and most oxidants }\end{array}$ \\
\hline & Others(PE, PP, PES) & $0.1 / 0.2$ & $<25$ & $\begin{array}{l}\text { Mainly } \\
\text { MF }\end{array}$ & Lowest manufacturing cost \\
\hline Inorganic & $\begin{array}{l}\text { Ceramic membrane, } \\
\text { metal membrane }\end{array}$ & $\begin{array}{c}0.1 / 0.5 / \\
1.0\end{array}$ & $<45$ & $\mathrm{MF} / \mathrm{UF}$ & $\begin{array}{l}\text { Excellent thermal and chemical } \\
\text { resistance }\end{array}$ \\
\hline
\end{tabular}

3 Table 2. Comparison of Several Membrane Configurations [41]

\begin{tabular}{lccc}
\hline Factors & $\begin{array}{c}\text { Plate/flat sheet } \\
\text { membrane }\end{array}$ & $\begin{array}{c}\text { Hollow fiber } \\
\text { membrane }\end{array}$ & $\begin{array}{c}\text { Tubular } \\
\text { membrane }\end{array}$ \\
\hline Membrane density & Moderate & High & Low \\
Arrangement & External/ & External/ \\
submerged & complicated & External/recycling \\
Module structure & submerged & Back washing & simple \\
Cleanability & simple & possible & Physical cleaning \\
Scaling resistance & Moderate & High & possible \\
Energy consumption & Average & Moderate & High \\
\hline
\end{tabular}


2 Table 3. Description of Different Parameters in Various AnMBR Configurations

\begin{tabular}{|c|c|c|c|c|c|c|c|c|c|}
\hline $\begin{array}{l}\text { Type of } \\
\text { wastewater }\end{array}$ & $\begin{array}{l}\text { Membrane } \\
\text { character }\end{array}$ & $\begin{array}{c}\text { Configuratio } \\
\mathrm{n}\end{array}$ & $\begin{array}{c}\text { Reactor } \\
\text { Volume (L) }\end{array}$ & $\begin{array}{l}\text { Influent } \\
\text { COD } \\
(\mathrm{mg} / \mathrm{L})\end{array}$ & Flux (LMH) & $\begin{array}{l}\text { Operating } \\
\text { condition }\end{array}$ & $\begin{array}{l}\mathrm{OLR}(\mathrm{kgCO} \\
\left.\mathrm{D} /\left(\mathrm{m}^{3} \mathrm{~d}\right)\right)\end{array}$ & $\begin{array}{c}\text { COD } \\
\text { removal }(\%)\end{array}$ & Reference \\
\hline $\begin{array}{l}\text { municipal } \\
\text { wastewater }\end{array}$ & $\begin{array}{l}\text { HFM } \\
\text { PVDF } \\
0.4 \mu \mathrm{m}\end{array}$ & IG-AnMBR & 20 & $422 \pm 74$ & $7.21-14.32$ & $\begin{array}{c}\text { HRT: } 4-12 \mathrm{~h} \\
\text { Temp: } 25^{\circ} \mathrm{C} \\
\text { MLVSS: } 10-15 \mathrm{~g} / \mathrm{L} \\
\text { pH: } 6.9-7.5\end{array}$ & $0.69-2.07$ & $89 \%$ & {$[57]$} \\
\hline $\begin{array}{l}\text { municipal } \\
\text { wastewater }\end{array}$ & HFM & IG-AnMBR & NA & $293-708$ & A & $\begin{array}{c}\text { HRT: } 6-22 \mathrm{~h} \\
\text { Temp: } 35 \pm 1^{\circ} \mathrm{C} \\
\text { pH: } 7.13 \\
\text { MLVSS: } 4.6-5.4 \mathrm{~g} / \mathrm{L}\end{array}$ & $0.29-2.85$ & $\begin{array}{c}64.4-83.49 \\
\%\end{array}$ & {$[58]$} \\
\hline $\begin{array}{l}\text { synthetic } \\
\text { domestic } \\
\text { wastewater }\end{array}$ & $\begin{array}{l}\text { HFM } \\
\text { PVDF } \\
0.1 \mu \mathrm{m}\end{array}$ & IG-AnMBR & 5 & & NA & $\begin{array}{l}\text { HRT: } 4.0 \pm 0.3 \mathrm{~h} \\
\text { Temp: } 10 / 18^{\circ} \mathrm{C}\end{array}$ & NA & $>85 \%$ & [59] \\
\hline $\begin{array}{l}\text { municipal } \\
\text { wastewater }\end{array}$ & $\begin{array}{l}\text { HFM } \\
\text { PVDF } \\
0.4 \mu \mathrm{m} \\
\end{array}$ & IG-AnMBR & 5000 & $300-500$ & $2.75-17.83$ & $\begin{array}{l}\text { HRT: } 6-48 \mathrm{~h} \\
\text { Temp: } 25^{\circ} \mathrm{C}\end{array}$ & $0.16-1.95$ & $>90 \%$ & {$[60]$} \\
\hline $\begin{array}{l}\text { municipal } \\
\text { wastewater }\end{array}$ & $\begin{array}{c}\text { HFM } \\
\text { PVDF } \\
0.03 \mu \mathrm{m}\end{array}$ & IG-AnMBR & NA & $160-860$ & $7.6-7.9$ & $\begin{array}{c}\text { HRT: } 11 \pm 3 \mathrm{~h} \\
\text { SRT: } 60 \pm 27 \mathrm{~d} \\
\text { Temp: } 13-32^{\circ} \mathrm{C} \\
\text { VSS: } 4.30-7.54 \mathrm{~g} / \mathrm{L}\end{array}$ & $0.8-1.8$ & $>90 \%$ & {$[61]$} \\
\hline $\begin{array}{l}\text { municipal } \\
\text { wastewater }\end{array}$ & $\begin{array}{l}\text { HFM } \\
\text { PVDF } \\
0.2 \mu \mathrm{m} \\
\end{array}$ & ES-AnMBR & 35 & $200-800$ & 6 & $\begin{array}{l}\text { HRT: } 2.2 \mathrm{~h} \\
\text { Temp: } 35^{\circ} \mathrm{C}\end{array}$ & 3 & $87 \%$ & {$[62]$} \\
\hline $\begin{array}{l}\text { synthetic } \\
\text { domestic } \\
\text { wastewater }\end{array}$ & $\begin{array}{c}\text { HFM } \\
\text { PVDF } \\
0.22 \mu \mathrm{m}\end{array}$ & IG-AnMBR & 4 & $320-360$ & 7 & $\begin{array}{c}\text { HRT: } 12 \mathrm{~h} \\
\text { Temp: } 20 \pm 0.5^{\circ} \mathrm{C} \\
\text { pH: } 7.0\end{array}$ & NA & $91.9 \pm 1.5 \%$ & {$[63]$} \\
\hline
\end{tabular}




\begin{tabular}{|c|c|c|c|c|c|c|c|c|c|}
\hline $\begin{array}{l}\text { municipal } \\
\text { wastewater }\end{array}$ & $\begin{array}{c}\text { HFM } \\
\text { PVDF } \\
0.04 \mu \mathrm{m}\end{array}$ & ES-AnMBR & 550 & $110-800$ & 17 & $\begin{array}{c}\text { HRT: } 8.5 \mathrm{~h} \\
\text { SRT: } 40-70 \mathrm{~d} \\
\text { Temp: } 23 \pm 1^{\circ} \mathrm{C} \\
\text { SS: } 5-15 \mathrm{~g} / \mathrm{L} \\
\text { pH: } 6.7-6.8 \\
\end{array}$ & $3.77-4.97$ & $93 \%$ & [64] \\
\hline $\begin{array}{l}\text { synthetic } \\
\text { domestic } \\
\text { wastewater }\end{array}$ & $\begin{array}{c}\text { TM } \\
\text { PVDF } \\
0.018 \mu \mathrm{m}\end{array}$ & ES-AnMBR & 3.3 & $310-480$ & NA & $\begin{array}{c}\text { HRT: } 6-14 \mathrm{~h} \\
\text { Temp: } 10 / 25^{\circ} \mathrm{C} \\
\text { VSS: } 2 \mathrm{~g} / \mathrm{L}\end{array}$ & NA & $>94 \%$ & [66] \\
\hline $\begin{array}{l}\text { synthetic } \\
\text { domestic } \\
\text { wastewater }\end{array}$ & $\begin{array}{c}\text { FS } \\
\text { CPE } \\
0.2 \mathrm{~m}\end{array}$ & IG-AnMBR & 6 & $700 \pm 100$ & $1.08-6.46$ & $\begin{array}{c}\text { HRT: } 848 \mathrm{~h} \\
\text { Temp: } 25 \pm 1^{\circ} \mathrm{C} \\
\text { pH: } 6.8-7.5 \\
\text { VSS: } 10 \mathrm{~g} / \mathrm{L}\end{array}$ & $0.35-2.1$ & $>90 \%$ & [67] \\
\hline $\begin{array}{l}\text { municipal } \\
\text { wastewater }\end{array}$ & $\begin{array}{l}\text { TM } \\
\text { PVDF } \\
0.1 \mu \mathrm{m}\end{array}$ & IG-AnMBR & 9 & $235-300$ & & $\begin{array}{c}\text { HRT: } 2.3 \mathrm{~h} \\
\text { Temp: } 10-25^{\circ} \mathrm{C}\end{array}$ & $1.2-2.3$ & $>89 \%$ & {$[68]$} \\
\hline $\begin{array}{l}\text { municipal } \\
\text { wastewater }\end{array}$ & $\begin{array}{c}\text { HFM } \\
\text { PVDF } \\
0.03 \mu \mathrm{m}\end{array}$ & IG-AnMBR & 1,760 & & 7.5 & $\begin{array}{l}\text { HRT: } 4.6-6.8 \mathrm{~h} \\
\text { Temp: } 8-30^{\circ} \mathrm{C}\end{array}$ & NA & $93 \pm 3 \%$ & [69] \\
\hline $\begin{array}{l}\text { synthetic } \\
\text { domestic } \\
\text { wastewater }\end{array}$ & $\begin{array}{l}\text { MT } \\
\text { PTFE } \\
1 \mu \mathrm{m}\end{array}$ & IG-AnMBR & 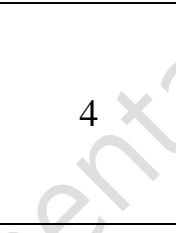 & 500 & 5 & $\begin{array}{c}\text { HRT: } 2.3 \mathrm{~h} \\
\text { Temp: } 15 / 25^{\circ} \mathrm{C} \\
\text { pH: } 6.8-7.1 \\
\text { SS: } 10 \mathrm{~g} / \mathrm{L} \\
\text { VSS: } 6 \mathrm{~g} / \mathrm{L} \\
\end{array}$ & 1 & $>85 \%$ & {$[54]$} \\
\hline $\begin{array}{l}\text { synthetic } \\
\text { domestic } \\
\text { wastewater }\end{array}$ & $\begin{array}{c}\text { FS } \\
\text { CPE } \\
0.2 \mu \mathrm{m}\end{array}$ & IG-AnMBR & 6 & $491 \pm 112$ & NA & $\begin{array}{c}\text { HRT: } 624 \mathrm{~h} \\
\text { Temp: } 25-10^{\circ} \mathrm{C} \\
\text { pH: } 7.0 \pm 0.5\end{array}$ & $0.74-1$ & $71-96 \%$ & {$[55]$} \\
\hline $\begin{array}{l}\text { municipal } \\
\text { wastewater }\end{array}$ & $\begin{array}{c}\text { HFM } \\
\text { PVDF } \\
0.04 / 0.08 \\
\mu \mathrm{m}\end{array}$ & IG-AnMBR & $125 / 1,500$ & $338 \pm 74$ & 6 & $\begin{array}{c}\text { HRT: } 16 \mathrm{~h} \\
\text { Temp: } 25-10^{\circ} \mathrm{C} \\
\text { pH: } 8.1 \pm 0.3 \\
\text { VSS: } 10 \mathrm{~g} / \mathrm{L}\end{array}$ & NA & $78-92 \%$ & [70] \\
\hline
\end{tabular}




\begin{tabular}{|l|c|c|c|c|c|c|c|c|}
\hline $\begin{array}{l}\text { municipal } \\
\text { wastewater }\end{array}$ & $\begin{array}{c}\text { HFM } \\
\text { PVDF } \\
0.045 \mu \mathrm{m}\end{array}$ & ES-AnMBR & 496 & $372 \pm 149$ & NA & $\begin{array}{r}\text { HRT: } 8-10 \mathrm{~h} \\
\text { Temp: } 10-28^{\circ} \mathrm{C}\end{array}$ & NA & $>89 \%$ \\
\hline $\begin{array}{l}\text { municipal } \\
\text { wastewater }\end{array}$ & $\begin{array}{c}\mathrm{HFM} \\
\mathrm{PVDF} \\
0.04 \mu \mathrm{m}\end{array}$ & ES-AnMBR & 550 & $252 \pm 59$ & 17 & $\begin{array}{r}\text { HRT: } 8.5 \mathrm{~h} \\
\text { Temp: } 23 \pm 1^{\circ} \mathrm{C} \\
\mathrm{pH}: 6.8\end{array}$ & NA & $90 \pm 2 \%$ \\
\hline
\end{tabular}

2 Table 4. Biogas Yield and Methane Conversion rate of AnMBRs

\begin{tabular}{|c|c|c|c|c|c|c|c|c|c|}
\hline $\begin{array}{l}\text { Type of } \\
\text { wastewater }\end{array}$ & $\begin{array}{l}\text { Membrae } \\
\text { character }\end{array}$ & Configuration & $\begin{array}{l}\text { Reactor } \\
\text { Volume } \\
\text { (L) }\end{array}$ & $\begin{array}{l}\text { Influent } \\
\text { COD } \\
(\mathrm{mg} / \mathrm{L})\end{array}$ & $\begin{array}{l}\text { Operating } \\
\text { condition }\end{array}$ & $\begin{array}{l}\text { Biogas } \\
\text { yield L/ } \\
(\mathrm{L} \\
\text { reactor } / \mathrm{d})\end{array}$ & $\begin{array}{c}\text { Methane yield } \\
\text { (mLCH4/gCODRemoved) }\end{array}$ & $\begin{array}{c}\text { Methane } \\
\text { conversionrate }\end{array}$ & Reference \\
\hline $\begin{array}{l}\text { municipal } \\
\text { wastewater }\end{array}$ & $\begin{array}{l}\text { HFM } \\
\text { PVDF } \\
0.4 \mu \mathrm{m}\end{array}$ & IG-AnMBR & 20 & $422 \pm 74$ & $\begin{array}{l}\text { HRT: } 4-12 \mathrm{~h} \\
\text { Temp: } 25^{\circ} \mathrm{C}\end{array}$ & 0.26 & 208 & $\mathrm{NA}$ & [54] \\
\hline $\begin{array}{l}\text { municipal } \\
\text { wastewater }\end{array}$ & $\begin{array}{l}\text { HFM } \\
\text { PVDF } \\
0.4 \mu \mathrm{m}\end{array}$ & IG-AnMBR & 5,000 & $300-500$ & $\begin{array}{l}\text { HRT: } 6-48 \mathrm{~h} \\
\text { Temp: } 25^{\circ} \mathrm{C}\end{array}$ & $50-2000$ & $187.5-218.7$ & $35 \%$ & [60] \\
\hline $\begin{array}{l}\text { municipal } \\
\text { wastewater }\end{array}$ & $\begin{array}{c}\text { HFM } \\
\text { PVDF } \\
0.03 \mu \mathrm{m}\end{array}$ & IG-AnMBR & $\overline{\mathrm{NA}}$ & $160-860$ & $\begin{array}{c}\text { HRT: } 11 \pm 3 \mathrm{~h} \\
\text { SRT: } 60 \pm 27 \mathrm{~d} \\
\text { Temp: } 13-32^{\circ} \mathrm{C} \\
\text { VSS: } 4.30-7.54 \mathrm{~g} / \mathrm{L}\end{array}$ & $\mathrm{NA}$ & $80-220$ & $\mathrm{NA}$ & [61] \\
\hline $\begin{array}{l}\text { municipal } \\
\text { wastewater }\end{array}$ & $\begin{array}{l}\text { HFM } \\
\text { PVDF } \\
0.2 \mu \mathrm{m}\end{array}$ & ES-AnMBR & 35 & $200-800$ & $\begin{array}{l}\text { HRT: } 2.2 \mathrm{~h} \\
\text { Temp: } 35^{\circ} \mathrm{C}\end{array}$ & 13.2 & 119 & $30 \%$ & [62] \\
\hline $\begin{array}{l}\text { synthetic } \\
\text { domestic } \\
\text { wastewater }\end{array}$ & $\begin{array}{c}\text { HFM } \\
\text { PVDF } \\
0.22 \mu \mathrm{m}\end{array}$ & IG-AnMBR & 4 & $320-360$ & $\begin{array}{c}\text { HRT: } 12 \mathrm{~h} \\
\text { Temp: } 20 \pm 0.5^{\circ} \mathrm{C} \\
\text { pH: } 7.0\end{array}$ & 0.163 & $160.5 \pm 5.6$ & $45.3 \%$ & [63] \\
\hline $\begin{array}{l}\text { synthetic } \\
\text { domestic } \\
\text { wastewater }\end{array}$ & $\begin{array}{l}\text { FSM } \\
\text { PVC } \\
0.2 \mu \mathrm{m}\end{array}$ & IG-AnMBR & 6 & $492 \pm 112$ & $\begin{array}{c}\text { Temp: } 25 \pm 1^{\circ} \mathrm{C} \\
\text { HRT }=12 \mathrm{~h}\end{array}$ & 0.352 & 320 & 86.9 & [73] \\
\hline
\end{tabular}




\begin{tabular}{|c|c|c|c|c|c|c|c|c|c|}
\hline $\begin{array}{l}\text { synthetic } \\
\text { domestic } \\
\text { wastewater }\end{array}$ & $\begin{array}{l}\text { FSM } \\
\text { PVDF } \\
0.2 \mu \mathrm{m}\end{array}$ & IG-AnMBR & 6 & $700 \pm 100$ & $\begin{array}{c}\text { Temp: } 25 \pm 1^{\circ} \mathrm{C} \\
\text { HRT: } 8 \mathrm{~h}\end{array}$ & 0.90 & 338 & $96.5 \%$ & [74] \\
\hline $\begin{array}{l}\text { synthetic } \\
\text { domestic } \\
\text { wastewater }\end{array}$ & $\begin{array}{c}\text { FSM } \\
\text { PVDF } \\
0.2 \mu \mathrm{m}\end{array}$ & IG-AnMBR & 6 & $670 \pm 100$ & $\begin{array}{c}\text { Temp: } 25^{\circ} \mathrm{C} \\
\text { HRT: } 8 \mathrm{~h}\end{array}$ & 0.72 & 326 & $93 \%$ & [75] \\
\hline $\begin{array}{l}\text { municipal } \\
\text { wastewater }\end{array}$ & $\begin{array}{c}\text { HFM } \\
0.045 \mu \mathrm{m}\end{array}$ & ES-AnMBR & 310 & $892 \pm 271$ & $\begin{array}{c}\text { Temp: } 6-30^{\circ} \mathrm{C} \\
\text { HRT: } 10-13.4 \mathrm{~h}\end{array}$ & 0.30 & 235 & $67.1 \%$ & [76] \\
\hline $\begin{array}{l}\text { municipal } \\
\text { wastewater }\end{array}$ & $\begin{array}{c}\text { FSM } \\
\text { Ceramic } \\
0.20 \mu \mathrm{m}\end{array}$ & IG-AnMBR & 3.6 & $330.4 \pm 89.8$ & $\begin{array}{c}\text { Temp: } 25-30^{\circ} \mathrm{C} \\
\text { HRT: } 7.5 \mathrm{~h}\end{array}$ & $0.128-0.139$ & $300 \pm 10$ & $85.7 \%$ & [77] \\
\hline
\end{tabular}

1 